\title{
Spatial organisation of groundwater dynamics and streamflow response from different hydropedological units in a montane catchment
}

\begin{tabular}{|r|l|}
\hline Journal: & Hydrological Processes \\
\hline Manuscript ID & HYP-15-0734.R1 \\
\hline Diley - Manuscript type: & Research Article \\
\hline Complete List of Authors: & $\begin{array}{l}\text { Blumstock, Maria; University of Aberdeen, School of Geosciences } \\
\text { Tetzlaff, Doerthe; University of Aberdeen, School of Geosciences } \\
\text { Dick, Jonathan; University of Aberdeen, School of Geosciences } \\
\text { Nuetzmann, Gunnar; Leibniz Institute of Freshwater Ecology and Inland } \\
\text { Fisheries, Ecohydrology } \\
\text { Soulsby, Chris; University of Aberdeen, School of Geosciences }\end{array}$ \\
\hline Keywords: & $\begin{array}{l}\text { groundwater, runoff processes, storage-discharge relationships, thresholds, } \\
\text { hillslope hydrology }\end{array}$ \\
\hline &
\end{tabular}

SCHOLARONE

Manuscripts 


\title{
Spatial organisation of groundwater dynamics and streamflow response from different hydropedological units in a montane catchment
}

\author{
Running head: Groundwater \& stream dynamics across different hydropedological units
}

Blumstock, M., Tetzlaff, D., Dick, J. J., Nuetzmann, G. ${ }^{1}$ and Soulsby, C.

\author{
School of Geosciences, University of Aberdeen \\ ${ }^{1}$ Leibniz Institute of Freshwater Ecology and Inland Fisheries, D-12587 Berlin, Germany
}

\begin{abstract}
Groundwater dynamics play an important role in runoff generation and hydrologic connectivity between hillslopes and streams. We monitored a network of 14 shallow groundwater (GW) wells in a $3.2 \mathrm{~km}^{2}$ experimental catchment in the Scottish Highlands. Wells were placed in three contrasting landscape units with different hydropedological characteristics and different topographic position relative to the stream network, encompassing a catena sequence from free draining podzols on steeper hillslopes to increasingly thick peats (histosols) in the valley bottom riparian zone. GW dynamics were characterised by statistical analyses of water table fluctuations, estimation of variabilities in lag times and hysteresis response in relation to streamflow. The three landscape units had distinct storage-discharge relationships and threshold responses with a certain GW level above which lateral flow dominates. Steeper hillslopes with freely draining podzols were characterised by GW fluctuations of around $150 \mathrm{~cm}$ in the underlying drift. GW usually showed peak response up to several hours after stream flow. During persistent wet periods the water table remained in the soil profile for short spells and connected shallow flow paths in the near surface horizons to the lower hillslopes. In the peaty gleys in the lower foot slopes, GW was characterised by a water table generally within $20 \mathrm{~cm}$ of the soil surface, though at some locations this could fall to $50 \mathrm{~cm}$ in extreme dry periods. GW responses were usually a few hours prior to the stream responses. In riparian peats, the water table was also usually less than $20 \mathrm{~cm}$ deep and responded several hours before the
\end{abstract}


stream. These riparian peat soils remain at, or very near saturation with near-continuous GWsurface water connectivity. In contrast, the steeper slopes remain disconnected for prolonged periods and need large recharge events to overcome storage thresholds. Groundwater responses vary seasonally, and landscape controls on the spatial organisation of GW dynamics are strongest at low flows and in small events. During wettest periods, limited storage and extensive saturation weaken such controls. This study demonstrated that montane catchments can have highly dynamic GW stores which are important in generating both storm flows and baseflows.

Key Words: Groundwater, runoff processes, storage-discharge relationships, thresholds, hillslope hydrology

\section{Introduction}

Over the past two decades numerous studies have shown that contrary to traditional assumptions, montane catchments can have significant dynamic groundwater (GW) stores (Neal et al., 1997; Soulsby et al., 1998; Haria \& Shand, 2004). More recent work has demonstrated the importance of such stores in generating both storm flows and baseflows in montane headwater catchments (Gannon et al., 2014; McMillan \& Srinivasan, 2015; Rinderer et al., 2014). Thus, maintaining water supplies and other ecosystem services - derived from downstream flows in larger rivers - depend on such montane GW sources (Price \& Egan, 2014). In addition to the provision of a range of ecosystem services, montane GW fluxes also provide buffering against hydroclimatic variability, particularly during droughts (Winter, 2007).

Montane catchments are usually characterised by thin soils and dynamic GW stores in drift or bedrock with poor aquifer properties (Soulsby et al., 2000; Aishlin and McNamara, 2011). Shallow GW flow paths usually dominate in smaller headwater catchments, while deeper GW sources become more important as catchment size increases (Shaw et al., 2014). Whilst some studies have 
pointed to the importance of fractures and faults in different types of rock formations as important conduits for mountain GW movement (Haria et al., 2013, Caulfield et al., 2014, Katsuyama et al., 2008), in many glaciated regions, superficial drift deposits often provide larger sources of GW (Soulsby et al., 1998; Detty \& McGuire 2010). For example, studies in the Brugga catchment in the Black Forest mountains, Germany, showed that around $70 \%$ of total runoff is generated from shallow GW in upper drifts and 20\% from deeper bedrock sources (Uhlenbrook et al., 2002; Koch et al., 2009). Drift deposits are often highly heterogeneous, and although the permeability and porosity is generally low, more permeable units, together with significant thicknesses can result in substantial aquifers that can sustain baseflows as well as responding dynamically to storm events (Tetzlaff \& Soulsby, 2008; Capell et al., 2012).

The influence of landscape characteristics and hydropedology on the spatial distribution and connectivity of aquifer systems in montane catchments has been elucidated at an increasing number of sites. Numerous studies have shown that GW in riparian zones and adjacent upslope zones have distinctly different water table level-discharge relationships. GW levels closest to the stream have been shown to be more in phase with discharge response while areas further away lagged behind (Seibert, 2003). However, the connectivity between these riparian and upland areas can be important as hillslope GW seepage often maintains high riparian water tables during low flow periods (McGuire \& McDonnell, 2010, Camporese et al., 2014). Others have identified threshold-like behaviour in these connections with rising GW levels on hillslopes producing transmissivity feedback by activating rapid near-surface flow paths through macropores and soil pipes which become hydrologically connected to the stream network and result in a rapid increase in runoff (Laudon et al., 2007; Haught \& Meerveld, 2011). Thus, the influence of landscape structure, topography and soils on spatial patterns of GW dynamics can be complex. 
Such studies are challenging traditional simplistic concepts of "groundwater-dominated" or "surface water dominated" river systems; rather showing frequent strong inter-linkages between deeper GW and near-surface flow paths. For example, saturation excess overland flow from histosol soils in riparian zones can be the largest source of runoff if seepage from upslope aquifers maintains water tables close to the soil surface and near-continuous surface connectivity with the channel network (Tetzlaff et al., 2014). In other situations, GW inputs to the stream may be by direct subsurface flow paths if surface saturation is not present (Vidon \& Hill, 2004). In many cases these spatial connections may be time variant: McGlynn et al. (2004) showed that in smaller events runoff was generated primarily in headwater riparian zones; while in larger events runoff was generated more uniformly across scales as connectedness shifts the system state from a network dominated catchment response to riparian-hillslope dominated catchment response. Others have shown similar inter-relationships, often with soil cover or hydropedology having a strong influence on the relative importance of shallow and deeper flow paths and water table dynamics (Tetzlaff et al., 2014; Gannon et al., 2014). In addition to such longer-term space-time variance, hysteretic behaviour in catchment storage-discharge relationships at the storm event scale may result from different response times of fast surface and slower subsurface flows. During rainfall events with dry antecedent conditions, streamflow peaks can precede hillslope response (clockwise loops), while for events with wet antecedent conditions, streamflow lags behind hillslope responses (counter clockwise loops) (Ambroise, 2004).

Despite the evident importance of mountain GW, data collection has been limited compared to other environments. Logistical challenges associated with equipment installation and drilling through hard rock and bouldery drift in steep, remote and often road-less terrain (Koch et al., 2009; Gabrielli et al., 2012) result in high costs (Batlle-Aguilar et al., 2014). Even non-invasive techniques such as geophysics are challenging in such environments (Soulsby et al., 2008). Thus, long-term data sets are limited and many have focused on GW dynamics and key controls during wet conditions at 
the hillslope scale (Seibert, 2003; Tromp-van Meerveld \& McDonnell, 2006a, b) or at the riparianhillslope interface (Detty \& McGuire, 2010), but until recently less has been done regarding catchment-wide variability in GW levels (Gannon et al., 2014; Rinderer et al., 2014, 2015).

In this paper, we report the results of monitoring 14 shallow GW wells in the Bruntland Burn, an intensively studied sub-basin of the Girnock experimental catchment in the Scottish Highlands. Previous field and modelling work has identified dominant sources of runoff at the catchment-scale and the associated landscape controls on their dynamics and associated transit times (Soulsby et al., 2007; Tetzlaff et al., 2007; Birkel et al., 2011a). More recent work has integrated hydrometric and tracer based studies to examine catchment storage dynamics (Birkel et al., 2011b). Whilst these studies have emphasised the importance of riparian wetlands as the dominant source of runoff (Tetzlaff et al., 2014), GW discharge provides both a major source of water to these wetlands throughout most of the year, as well as a direct flux into the channel network to sustain the lowest flows (Birkel et al., 2011a; 2014). GW also provides a large store of water that mixes with incoming precipitation to affect the attenuation and lag observed in stream water conservative stable isotope tracers compared to isotopes in precipitation (Tetzlaff et al., 2014). However, despite this, little is known about the heterogeneous nature of GW dynamics at the catchment scale for the Bruntland Burn, the associated landscape and hydropedological controls and how they affect stream flow response. In this study, we sought to address this knowledge gap through the following specific objectives: to (a) characterise the spatial organisation and temporal dynamics of shallow GW levels under different hydropedological units; (b) identify the dominant landscape controls on GW dynamics and (c) assess the effects of these dynamics on runoff generation.

\section{Study site}

The Bruntland Burn catchment (BB, $3.2 \mathrm{~km}^{2}$, Lat.: 57.043576 , Long.: -3.1219050 ) is located in the Cairngorms National Park, NE Scotland (Figure 1, Table 1). A detailed description of the catchment is 
provided elsewhere (Birkel et al., 2010; Birkel et al., 2011a, b). It spans an elevation range from 248 to 539 m.a.s.I with the highest point located at the south western edge of the catchment. The climate is at the temperate/boreal transition, with a maritime influence usually giving mild winters and cool summers. Daily average air and stream temperatures are $7.4^{\circ} \mathrm{C}$ and $6.3^{\circ} \mathrm{C}$, respectively (Hannah et al., 2008). Annual mean precipitation is $1000 \mathrm{~mm}$ with limited seasonality, though the wettest months are usually November to January. Half of the rain usually falls during low intensity events of less than $10 \mathrm{~mm} \mathrm{~d}^{-1} ; 75 \%$ are below $20 \mathrm{~mm} \mathrm{~d}^{-1}$. Usually less than $5 \%$ of the annual precipitation falls as snow. Evapotranspiration typically accounts for around 400mm (Birkel et al., 2011a). Stream discharge is monitored at the catchment outlet. Mean annual discharge is $1.6 \mathrm{~mm} \mathrm{~d}^{-1}$. High and low annual discharges, expressed as $Q_{5}$ and $Q_{95}$, are $6.2 \mathrm{~mm} \mathrm{~d}^{-1}$ and $0.4 \mathrm{~mm} \mathrm{~d}^{-1}$, respectively (for period June 2013-May 2014). Modelling studies suggest that GW accounts for about $25-35 \%$ of annual stream discharge (Birkel et al., 2011a, b).

The landscape is of glacial origin. Flat wide valley bottoms feature large dynamic saturation areas in the riparian zone with high Topographic Wetness Index (TWI, $\ln (\alpha / \tan \beta)$, where $\alpha$ is the upslope contributing area per unit contour length and $\beta$ is the local slope) values, spanning $2-40 \%$ of the total catchment area dependent on wetness conditions (Figure 1b; Birkel et al., 2011b). Due to the glacial past, most of the catchment is underlain by at least several meters of low-permeability glacial drift deposits, generally consisting of medium textured sandy-gravelly till with abundant clasts. The drift has a porosity of around $20 \%$ and permeabilities in the range $10^{-4}$ to $10^{-2} \mathrm{~m} \mathrm{~d}^{-1}$ (Blumstock et al., 2015). Bedrock outcrops are found at higher elevation at the northern edge of the catchment. Electrical Resistivity Tomography (ERT) surveys in 2013 revealed drift depths of 7 to $40 \mathrm{~m}$ in the valley bottom (Soulsby et al., in review).

The stream flows across two distinct geologic units (Figure 1c) with low permeability igneous rock (granite) dominating downstream areas in the north-eastern sector of the catchment. Further 
upstream, to the south-west, the bedrock is comprised of low permeability schist and other metasediments in higher elevation areas. Due to the poor aquifer properties of the bedrock and the overlying extensive drift cover, the drifts are expected to be the largest source of GW storage in the BB. Previous studies by Soulsby et al. (2005) have indicated that GW recharge mainly occurs through more freely draining peaty podzols at the steeper hillslopes. A fraction of the GW might then drain quickly through the shallow fracture systems or glacial deposits and discharge in valley bottom areas, either emerging as seepage on lower hillslopes or directly into the stream (Malcolm et al., 2006).

The catchment is characterised by three major hydropedological units: The quasi-permanently saturated areas in the valley bottoms are comprised of $50-200 \mathrm{~cm}$ deep poorly draining peat ( $\mathrm{P}$, Histosols). The lower footslopes are comprised of peaty gleyed (PG) soils with $30-40 \mathrm{~cm}$ of peat. These soils are saturated for the majority of the year and generate substantial amounts of saturation excess overland flow and shallow lateral flow in more permeable organic surface horizons in the upper $20 \mathrm{~cm}$ of the soil profile (Tetzlaff et al., 2007). Below this layer, the older peat (or mineral horizons in the gley soils) is less permeable and vertical drainage is impeded. Drier, peaty podzols (PP) are located on the steeper hillslopes which are primarily dominated by heather (Calluna vulgaris). Here, vertical drainage facilitates GW recharge with the possibility of deeper sub-surface flow at the soil-bedrock interface (Birkel et al., 2011a). However, the podzol soil profile is characterised by a well-structured porous $O$ horizon in the upper $20 \mathrm{~cm}$ which is more permeable than the underlying mineral subsoil and can generate lateral subsurface storm flow if the profile becomes saturated (Soulsby et al., 2015). The upper hillslopes are comprised of rankers, 20 to $50 \mathrm{~cm}$ in depth which overly the bedrock or frost shattered regolith and have limited storage.

As in most parts of the Scottish Highlands, extensive land management together with high levels of grazing by red deer (Cervus elaphus), sheep and (historically) cattle have resulted in widespread 
deforestation. Thus, areas of coniferous forest (primarily Scots Pine (Pinus sylvestris)) cover only 11\% of total catchment area, and are only found in plantations within fenced areas near the BB outlet, or naturally forested parts along the steeper more inaccessible areas at higher altitude. P and PG soils are dominated by blanket bog vegetation such as Sphagnum spp. mosses, bog myrtle (Myrica gale) and purple moor grass (Molinia caerulea) (Figure 1d).

\section{Data and Methods}

Shallow GW wells were constructed from PVC pipes (3.2cm internal diameter) with holes pierced every $10 \mathrm{~cm}$ in the lower screened length. Eleven wells were installed by hand augering in June 2011 and supplemented by three additional ones in May 2013. Water levels were recorded with Odyssey capacitance loggers (1-1.5m length, approx. $0.8 \mathrm{~cm}$ resolution, Odyssey by Dataflow Systems Pty Ltd, New Zealand), at various distances away from the stream (1-544m). GW loggers were stratified according to the surrounding dominant soil type, with six loggers being installed in peaty soils (P1-6), five in peaty gleyed soils (PG1-5) and three (PP1-3) are located in peaty podzols (Figure 1d; Table2). GW dynamics were recorded at $15 \mathrm{~min}$ intervals and checked manually approximately every 2 months as well as corrected for potential offset. Depth to GW table was related to soil surface ( $\hat{=}$ $0 \mathrm{~cm})$, with negative values indicating a water table below soil surface and positive values indicating standing water or surface runoff which is common in the peaty soils in the valley bottom. The glacial drift deposits with many large boulders complicated borehole installations, especially along the upper hillslope, hence the lower number of installations. Thus, maximum recordable water level depth varied between -50 to $-125 \mathrm{~cm}$, though the ERT surveys indicated that most of the drift was saturated below these depths. Prior to installation, the loggers were calibrated following the Odyssey manual (Dataflow Systems Pty Ltd). Site maintenance and data downloads were done on a monthly basis. There were some periods when GW levels at a few loggers were below the maximum recordable GW level depth. In these cases, the actual GW levels have been interpolated on the basis of assuming a constant rate of recession prior to the recovery in levels. 
A $0.2 \mathrm{~mm}$ Davis tipping bucket rain gauge connected to an Odyssey data logger has been located at the BB outlet since June 2011. A second rain gauge was installed near GW loggers PG1 and PG2 in December 2013 (Figure 1). Data from a nearby ( $2 \mathrm{~km})$ weather station operated by Marine Science Scotland's Freshwater Laboratory were used to correct obviously spurious or missing precipitation data. Stream stage height was monitored from 2011 at the BB outlet at a $15 \mathrm{~min}$ interval, also using an Odyssey capacitance logger. Stream discharge was calculated using a regularly updated stagedischarge rating equation.

We based most of our statistical analysis on data from the period $1^{\text {st }}$ of June 2013 to $31^{\text {st }}$ of May 2014. This comprised a full year with complete data capture from all the loggers. It also showed the GW response to an unusually warm, dry summer in 2013 (which equated to a drought of $\sim 10$ year return period), the subsequent re-wetting and an extremely wet winter period in January 2014 (which also had $\sim 10$ year return period). Multivariate statistical (Principal Components Analysis, PCA; Hierarchical Cluster Analysis, HCA) and correlation analyses were performed in order to identify factors controlling spatio-temporal GW dynamics. Two individual runs were conducted for PCA and HCA analysis. The first run was based on topographical landscape characteristics (slope, wetness index etc.) and the second on characteristics during precipitation events (median and range of each GW level, GW peak to runoff peak lag times etc.). PCA was applied to identify factors that explain the spatial variability of the water table and to find groups of variables influencing GW response on the basis of correlation. HCA focused on identifying similar GW locations with distinct hydrological characteristics using the Ward method "Ward.D2" and the Euclidean distance as a measure of dissimilarity (R Development Core Team, 2009).

Additionally, cross correlation was used to determine if the GW response at a certain point in the catchment precedes or lags the stream response. The Spearman rank correlation coefficient of the 
relation between discharge and transient GW level was optimized by varying lag times for 24 individual rainfall events (six for each season) to find the peak-to-peak lag time giving the best correlation. This was necessary for the loggers in the peat and peaty gley soils as the water table rises were often small and multi-peaked due to high sensitivity to sub-hourly variability in precipitation inputs. The peak-to-peak lag time was defined as the time difference between the time of peak GW table and the time of peak discharge. Thus, a positive lag time means that discharge peaks earlier than the water table and vice versa for a negative lag time. The analysis was done with $15 \mathrm{~min}$ data. The 24 rainfall events were identified manually from the stream flow records, considering that data from at least six GW wells per rainfall event were needed to be available per event. For further interpretation, only lag times based on a statistically significant correlation $(p<0.05)$ between GW levels and discharge were used. Rejections of events on the basis of low correlations were taken as indicative of weaker relationships between GW response and stream flow.

Furthermore, a kriging method was applied to investigate the response of the monitored part of the BB catchment GW system using "gstat" (R Development Core Team, 2009). Kriging is a geostatistical technique which was used to interpolate water table levels at an unobserved location based on nearer water table measurements and random function theory to produce an interpolated 2D GW spatial distribution image. Kriging analysis was undertaken on the responses for several precipitation events, including the pre-event, peak-event and post-event periods.

\section{Results}

\subsection{Spatial and temporal variability in groundwater response}

Most of $P$ and PG site loggers showed very small variability in GW levels in the valley bottom (Fig. 2). The mean and median water table depth was within the upper $35 \mathrm{~cm}$ of the soil with a low standard deviation (Table 2). Within the P sites, P3 was anomalous in having a deeper water table falling 
below $-50 \mathrm{~cm}$ in the driest period. However, like the other sites, the GW logger frequently detected a water table within $5 \mathrm{~cm}$ of the ground surface and was responsive to all precipitation events. Likewise, there were some differences within the PG sites, with PG1 and PG2 showing more marked evidence of dry season drawdown, though this was restricted to the summer drought of 2013. On the steeper slopes, the PP loggers had mean GW levels deeper than $-35 \mathrm{~cm}$ and much higher water table fluctuations of around $100-150 \mathrm{~cm}$. For wet periods the water-table remained within the soil profile (upper $40 \mathrm{~cm}$ ), but receded into the drift during the drier periods.

These temporal dynamics of GW responses were directly related to precipitation inputs at most sites (see examples in Figure 3). Precipitation showed unusual variation during the monitoring period, with the dry conditions of summer 2013 (a drought with 10 year return period), preceding a wet autumn and winter with January rainfall having a 10 year return period. Precipitation totals on raindays ranged from 0.02 to $29.0 \mathrm{~mm} \mathrm{~d}^{-1}$, and stream flow ranged from a minimum of $0.3 \mathrm{~mm} \mathrm{~d}^{-1}$ in September 2013 to a maximum of $19.2 \mathrm{~mm} \mathrm{~d}^{-1}$ during the wettest period in January. A comparison to annual high and low discharges, expressed as $Q_{5}\left(6.2 \mathrm{~mm} \mathrm{~d}^{-1}\right)$ and $Q_{95}\left(0.4 \mathrm{~mm} \mathrm{~d}^{-1}\right)$ (for period June 2012 to May 2013), illustrates these unusual meteorological conditions (Blumstock et al., 2015). During the monitoring period, the maximum measured value was 4.5 times higher than the $Q_{5}$ value and the minimum observed value being half of the $Q_{95}$ value. Almost all precipitation events $>1 \mathrm{~mm}$ caused a response in the stream. The discharge response is very flashy and water table changes were evident under all three hydropedological units in most events. The peat sites usually showed almost immediate, but small, water table responses to precipitation (see P1 in Figure 3b). As the water table was always close to the soil surface, precipitation triggered shallow lateral flow in the very permeable surface horizons of the peat acrotelm (the more permeable upper $20 \mathrm{~cm}$ of the peat profile) generating saturation overland flow which moved directly to the stream (Tetzlaff et al., 2007; Geris et al., 2015). This was visually evident in the field and occurred even during the summer when the water table was slightly deeper. A broadly similar response was evident in the PG sites, at 
least during wet periods, when there was a rapid but small water table rise (see PG2 in Fig 3c) which again triggered lateral flow and maintained connectivity with the stream. However, during the dry period in summer and autumn 2013 the water table dropped into the subsoil and remained there until re-wetting in the autumn. The wetter periods in the steeper slopes at the PP sites (see PP2 in Fig 3d) resulted in discontinuous periods of high water tables, and during these times responses were rapid and the water table extended into the soil profile. However, during prolonged dry periods the water table dropped into the drift and depths below $-100 \mathrm{~cm}$ indicating limited recharge in summer of 2013 . Large precipitation events $(>20 \mathrm{~mm})$ were then needed to allow sufficient recharge for the water table to rise back into soil from the drift layer in the following autumn and winter. During wetter periods when the water table extended into the more permeable near-surface horizons (i.e. within $20 \mathrm{~cm}$ of the soil surface), lateral downslope movement can occur connecting the steeper hillslopes to the riparian areas downslope (Tetzlaff et al., 2014).

The differences in water table behaviour in the different soil units can be summarised in terms of the percentage time that a particular soil horizon was saturated and below the water table (Figure 4 and Table 3). The peats were fully saturated for 13 to $78 \%$ of the period of record (except P1, P2 and 3), whilst the base of O-horizon (water table $\geq 20 \mathrm{~cm}$ ) was $100 \%$ saturated at most sites. In contrast, for the podzol site, the water table was in the upper $20 \mathrm{~cm}$ for only $7-18 \%$ of the study period, whilst full saturation was only observed at site PP1 (14\%, Figure 4, Table 3).

The non-linear nature of the relationship between water table variation at selected sites within the three landscape units and the stream flow response is shown in Figure 5. The water table variation was normalised by the maximum range (Fig 5 a-f) for the two example sites in each hydropedological unit. For the wettest peat sites (P1), which remained saturated with the water table near the soil surface, constant seepage occurred throughout the year. The absolute and normalised GW response to individual events was small as high precipitation simply resulted in more lateral flow. P2 showed more variability which reflects the slightly deeper water table and the effects of differently sized 
precipitation events, especially when the data were normalised. However, low correlations $(<0.2)$ resulted between GW levels and discharge. For the PG sites, water table drawdown was generally limited to the driest periods when stream flow was low. However, during the following re-wetting event, PG2 still had a low water table in some of the initial stream flow increases. But generally, the high water table resulted in increased lateral flow in most stream flow events, either as overland flow (indicated by positive GW level measurements and also observed in the field) or in the transmissive upper soil layers (Tetzlaff et al., 2014; Blumstock et al., 2015; Geris et al., 2015). At the PP sites, more absolute variability was evident, especially at PP2. Here, there was a clearer threshold like behaviour, with some increases in stream flow occurring when the water table was $30-50 \mathrm{~cm}$ deep, but these were only for smaller runoff events. In the largest events the water table rises into the upper $20 \mathrm{~cm}$ of the soil profile, with lateral flow occurring in the more transmissive organic soil horizon. Consequently, at the PP sites, there was a strong relationship between discharge and GW level with a Spearman rank correlation coefficient varying between 0.8 and 0.82 .

We tested for a simple relationship between GW dynamics and topographic position in terms of the distance from stream (Figure 6). Whilst a general significant negative relationship of increasing median GW level and distance from stream was evident $(r-0.66)$, which differentiated the P and PG sites from the three PP sites, there was overlap and PP3 showed a shallower depth than PP1 and PP2. There was a strong linear correlation between both median GW levels and groundwater level range and distance to stream: the closer to the stream the higher the mean GW levels and the lower the variation of GW levels. Within about $80 \mathrm{~m}$ of the stream the median GW depth was within the upper $20 \mathrm{~cm}$ of the soil with a standard deviation of $10 \mathrm{~cm}$. At distances more than $200 \mathrm{~m}$ from the stream the median depth was below $25 \mathrm{~cm}$ and standard deviation greater than $30 \mathrm{~cm}$. The influence of topography was much stronger in the relationship for the standard deviation in GW level and distance to the stream, with an $r$ of 0.83 . 


\subsection{Temporal response of groundwater relative to stream flow}

The response times of GW levels, in terms of GW peak to stream flow peak lag times, were determined for 24 rainfall events during four different seasons with 6 events per season (Table 4 and Figure 7). Generally, GW tended to respond before discharge (i.e. negative lag times). Only a few sites, usually further away from the stream (notably the upslope PP wells), showed a delayed response (positive lag times) on some occasions. There was seasonality in these timings; in wetter periods in spring and winter virtually all sites showed negative lag times. In the dry summer and autumn re-wetting, some events had longer lag times, especially for sites further from the stream. Wells closer to stream had similar lag times, which remained negative meaning that GW peaks prior to discharge (typically by 1-4 hours) throughout the whole year. Table 4 also shows that a greater proportion of the events at the PP sites had non-significant correlations indicating a less clear link with the stream response, especially for smaller events.

Figures 8 and 9 show the spatially interpolated GW dynamics during two rainfall events with dry and wet antecedent conditions in July 2013 and January 2014, respectively. The first event followed an unusually dry period in June and July 2013. An initial precipitation event of $16 \mathrm{~mm}$ on $23^{\text {rd }}$ July was followed by an event of more than $40 \mathrm{~mm}$ over $28^{\text {th }}-30^{\text {th }}$ July which caused a substantial stream storm flow response (Blumstock et al., 2015). There was initially high spatial variability in GW levels. Close to the stream, levels were generally within the upper $-20 \mathrm{~cm}$, though they were much deeper at the upper hillslope (around $-150 \mathrm{~cm}$ ). Responses close to the stream were rapid (within just few hours, 4 hours maximum), and as the event progressed, the water table rose on the steeper hillslopes. By the $29^{\text {th }}$ of July, the water table depth was more uniform $(-10 \mathrm{~cm})$ across much of the investigated area, which coincided with the maximum discharge peak. During the hydrograph recession, the GW levels began to initially fall on the upper hillslopes (where they were still around $-30 \mathrm{~cm}$ at the event peak) and later close to the stream, reaching depths of $-20 \mathrm{~cm}$ (in the valley bottom) and $-50 \mathrm{~cm}$ (on hillslopes) four days after the rainfall event stopped. 
The January 2014 event followed a very wet period over the preceding month, and initial GW levels were much higher than prior the July 2013 event. The main precipitation during the event occurred on the $29^{\text {th }}$ and $30^{\text {th }}$ January when around $45 \mathrm{~mm}$ of rain fell. At the start of the event GW levels were within the upper $10 \mathrm{~cm}$ of the soil profile across the catchment. GW levels rose a few centimetres between the $24^{\text {th }}$ and $28^{\text {th }}$ of January as each day had between $2-10 \mathrm{~mm}$ of precipitation, resulting in an increase in stream flows. By the $29^{\text {th }}$ of January, the day of maximum stream discharge, the water table was at the ground surface in the valley bottom, and was actually above the ground surface on the upper hillslopes. This apparent contradiction can be explained by extreme wetness of the catchment, which resulted in a large expansion of the saturation zone and the connection of upper hillslopes to the riparian area by overland flow (Birkel et a., 2011a). Because of the high antecedent precipitation, there was very little storage capacity in the catchment soils with a consequent high proportion of overland flow. In the flat valley bottom, saturation overland flow from the saturated peat soils flowed relatively fast through well-established zero-order channels connecting the peatland to the channel network. In contrast, on the steeper hillslopes, the heather vegetation creates a higher degree of hydraulic roughness, slowing down water flow rates despite overland flow being generated from upslope areas. The water table started falling again on $30^{\text {th }}$ of January 2014 with the cessation of rainfall. This was most marked on the upper slopes as the soil profiles slowly drained and the water table returned back below the soil surface, whilst levels remained high in the valley bottom area.

\subsection{Landscape controls on groundwater dynamics}

To explore the integrated landscape controls on GW dynamics, in terms of range and lag times, different topographic indices were used in a more formal correlation analysis (see Figure 10). Strongest statistically significant correlations were between distance to stream, slope and topographic wetness index (TWI) with both $G W L_{\text {Range }}$ and $t_{R \text {, Std.Dev. }}$. The further away from the stream, 
the higher were the ranges in GW level dynamics and the more variable were the lag times. The wetter the location (indicated by high TWI and low slope), the less variable were the lag times and lower the variability in GW changes.

We also quantified the temporal variation in the correlation between GW levels and TWI (Figure 11) by correlating the GW levels at each logger with its respective TWI on each day. When $p$ was $>0.1$ then data were removed from the plot. The average correlation was 0.57 , however, this varied. Highest correlations were found during driest conditions - indeed just prior to the event in July 2013 shown in Figure 8 - where water tables were high in valley bottom sites with a high TWI and low in upslope sites with a low TWI. In contrast, the lowest correlation occurred during the wettest event in January 2014 - shown in Figure 9 - as the extensive saturation was largely independent of topography, but reflected the high precipitation inputs and low storage.

A hierarchical cluster analysis was also carried out for the 14 sites. This clearly differentiated the $P$ and PG wells (closer to stream) and the PP wells (further upslope) (Figure 12). Wells located close to each other (e.g. P5, P6 and PG4) clustered as sub-groups. When combined in a PCA, the resulting axes explained $83 \%$ of the variance as a combination of the characteristics of GW behaviour and topographic characteristics (Figure 13). The water table responses of all sites were more or less evenly distributed in PCA space. PP loggers were slightly separated based on distance to stream and slope, $\mathrm{P}$ and PG wells were mixed together mainly based on TWI and a combination of $t_{R}$ (median, Std. dev.) and GW level median/mean.

\section{Discussion}

\subsection{Spatial and temporal variability of groundwater dynamics}

Groundwater dynamics play an important role in runoff generation and hydrologic connectivity between hillslopes and streams as they exert strong controls on lateral subsurface stormflow (Weiler 
et al. 2005). The connectivity between riparian and upland areas is also important during low flow periods when hillslope GW seepage often maintains high riparian water tables (Camporese et al., 2014). In many cases, these spatial connections are time variant (McGlynn et al., 2004). Our investigation showed that GW dynamics in different landscape units and under different hydropedological units exhibited contrasting characteristics. The peat ( $\mathrm{P}$ loggers) sites had limited GW variability, with the water table remaining high throughout the study, and responses to precipitation being small as lateral flows were immediately initiated inhibiting deep ponding of water on the surface. In the peaty gleys (PGs) a broadly similar response was evident apart from during drier periods when the water table retreated into the mineral subsoil. In the PG sites the weathered drift in the subsoil is topped by a shallow organic soil layer with macropores which can cause rapid horizontal drainage when the water table rises towards the soil surface. For the peaty podzols (PPs), responses were most marked, with the rising limb always much steeper than the falling limb of the GW hydrograph. At these sites, much higher amounts of precipitation and recharge were needed to cause the GW to rise into the soil profile and connecting the upper hillslopes with the lower hillslopes and valley bottom. Volumetric soil moisture values VSMC in the upper $10 \mathrm{~cm}$ of the peat and peaty podzol were $0.83 \pm 0.02$ and $0.37 \pm 0.14$ VSMC (average values \pm standard deviation), respectively (Geris et al., 2015). Even though vertical drainage predominates, significant soil moisture deficits developed (0.77 VSMC in the peat and 0.23 VSMC in the peaty podzol). Whilst such differences equated to soil moisture deficit of $\sim-20 \mathrm{~mm}$ in the peats, they could reach almost $-100 \mathrm{~mm}$ in the podzols giving different rainfall thresholds for re-wetting. Groundwater dynamics along the three contrasting landscape units are summarised conceptually in Figure 14 for the dry (summer) and the wet (winter) period.

The findings contribute to insights from studies elsewhere that have shown the relative importance of soils and hydropedology in determining GW response (Gannon et al, 2014). This shows different relative roles for hydrologically responsive soils with dominant lateral flow paths and little recharge 
to depth. In contrast, the more freely draining soils are dominated by vertical flow paths that recharge into GW (Capell et al., 2012). Other studies have shown that in catchments with transmissive soils, soil characteristics such as soil depth (Penna et al., 2015) and saturated hydraulic conductivity (Bachmair \& Weiler 2012) were stronger predictors for variability in GW dynamics than topography. The spatial distribution of soils reflects landscape position amongst other pedogenic factors and contributes to the frequency, duration, and depth of transient water table incursions (Bailey et al., 2014). Our results here are similar to those of Haught \& Meerveld (2011) who found a lack of a persistent water table at upper slope locations and low correlation between the water table responses at the upper and lower hillslope due to periods of connection and disconnection. The study by Blumstock et al. (2015) supports these findings as stream water analysis right after the last winter rain showed a highly homogenous stream chemistry, which coincided with dominant nearsurface drainage from acidic riparian peat soils. As the drought progressed stream chemistry became increasingly enriched and highly variable along the stream with weathering-derived solutes as dominance of diverse deep GW sources to stream flow increased.

The temporal dynamics of GW in the different landscape units showed spatial organisation that contrasted not only at an event scale, as indicated above, but also seasonally. Whilst in times of high antecedent wetness, water table levels were high at all sites; in drier conditions water tables were much more variable throughout the catchment. The lower hillslopes with peat soils were connected longer to the stream than the upslope zone which connected only after large precipitation events. The fact that the water table remained in the upper $150 \mathrm{~cm}$ of the drift throughout the catchment implies slow hillslope flow paths in the deeper drift, consistent with limited bedrock infiltration. Certainly, recent geochemical evidence suggests that GW in the drift is the main aquifer in the catchment that contributes to stream flow generation, particularly in the lower valley bottom (Blumstock et al., 2015). 


\subsection{Temporal dynamics in relation to stream flow: events, seasons and inter-annual variation}

The lag times between GW and stream water responses exhibited seasonal patterns, being more substantial and variable in summer and autumn, while less marked and less variable in winter. This resulted from lower summer rainfall and higher evaporation which caused soil moisture deficits limiting connectivity between the upper and lower hillslopes. Even in winter, the upper hillslopes can generally contribute only limited fluxes directly to stream runoff, except during large events (Birkel et al, 2015) which was also found at other sites (e.g. von Freyberg et al., 2014). In contrast, shallow GW in the lower hillslope zone responded rapidly to precipitation, contributing most to storm runoff which was also reflected in strong correlations between GW loggers together with the small negative lag times (Soulsby et al., 2015).

Seasonal variations in lag times in the saturated peat soils showed limited dependence on antecedent hydro-climatic conditions; with small negative lag times evidencing contributions to storm runoff with exceptions only during the driest antecedent conditions with small soil moisture deficits. In contrast, in upslope areas, the loggers further away from the stream generally also had negative lag times, though these were more variable and sometimes positive. More negative lag times between peak streamflow and peak GW level developed with increasing antecedent moisture conditions. This temporal variability in the piezometric response is consistent with that observed by Penna et al. (2014) in that soil depth and hillslope topography lead to consistent hysteretic behaviour in GW dynamics. Our results showed that the spatial variability of water tables was highest or lowest during dry and wet conditions, respectively.

\subsection{Dominant landscape controls on groundwater contributions/dynamics}

The landscape controls on GW dynamics in the Bruntland Burn catchment indicated by the PCA analysis reflect the inter-related effects of geologic and geomorphic history. Landscape evolution has set the large scale boundary conditions in terms of topography and distribution of drift materials, 
which in turn have influenced the co-development of soils and vegetation communities. The steeper slopes in the catchment have more freely draining soils which mostly facilitate GW recharge through vertical drainage. On the catchment interfluves, where the soils are shallow and fractured rock lies beneath, the storage capacity is low and water rapidly moves downslope at depth into the steeper hillslopes. These are dominated by the deeper peaty podzol soils which overlie drift deposits. This change in soil depth acts as first-order control in delivering runoff to the riparian area as has been shown elsewhere (e.g. Buttle et al., 2004; Hopp \& McDonnell, 2009). In the riparian zone, the extensive wetlands act as important mixing zones which integrate hillslope drainage both within the surface and subsurface (Tetzlaff et al., 2014).

The use of topographic characteristics (e.g. elevation, slope, TWI) to predict GW levels at the catchment scale is an area of interest in catchment hydrology due to the utility of its common explicit integration into hydrological models (Nippgen et al., 2015). These indices can control matrix potential and downslope flow (Anderson and Burt, 1978) as well as subsurface saturated areas (Fujimoto et al., 2008). These relationships between topography and subsurface flow dynamics have also been demonstrated theoretically (Harman and Sivapalan, 2009). GW dynamics in the Bruntland Burn correlated quite well with many topographic measures (e.g. distance from stream etc.) though the temporal correlation between TWI and GW levels was perhaps the most insightful. The correlation was highest during drier periods when the water tables were lowest and showed the biggest contrasts between the hillslope and riparian sites. However, the correlation decreased during rainfall events becoming weakest in the largest events. This is consistent with the effects of rainfall input, limited storage and surface flow redistribution overwhelming the normal topographic controls (Smith et al., 2014). This is somewhat different to recent work by Rinderer et al. (2014) who found in a pre-alpine catchment dominated by subsurface storm flow that correlations were strongest when GW levels were high and changed slowly, e.g. when catchment was gradually draining after events or during snowmelt in spring. At such times the TWI assumptions of steady 
state conditions and connected upslope contributing areas with surface slope as a proxy of the hydraulic gradient were fulfilled best. These assumptions were least appropriate during long dry periods, when parts of the catchment drained differently and became disconnected.

Although it has been shown that bedrock topography may be more important than surface topography in controlling the GW response (Freer et al., 2002; Graham et al., 2010; Tromp-van Meerveld \& McDonnell, 2006a, b), this influence seems to be less direct in valleys filled with glacial drift deposits. This reflects the dominance of near-surface flow paths which in turn reflect hydropedological characteristics rather than the influence of deeper-bedrock flow paths. At larger scales others have shown similar links between hillslope connectivity and shallow riparian GW. For example, Rodgers et al. (2004) demonstrated the links between shallow GW flow systems at the edge of a braided floodplain (that were recharged by hillslope drainage and effluent streams) and deeper GW closer to the main channel (that was upwelling through the hyporheic zone downstream). However, it is still an open question how GW, that becomes too deep to contribute to headwater tributary flow, and shallower flow paths which dominate tributary discharge, are linked together (Costelloe et al., 2014). There is also a question over the spatial scales of interactions. Some GW flow paths only contribute to streamflow generation at large scales; thus, large catchments may be more than simply the aggregation of hillslopes and small catchments. This is important for modeling purposes whereas the breakpoint in such scaling relationships is usually unknown (Frisbee et al., 2011).

\section{Conclusion}

Montane catchments can have significant GW stores which can be highly dynamic in time and space and are important in generating both storm flows and baseflows. Such GW stores play a crucial role in maintaining water supplies, providing a range of ecosystem services and creating buffer capacity against hydroclimatic variability, particularly during droughts. The present study focused on the 
effects of landscape and hydropedological controls on the spatio-temporal GW dynamics in a montane headwater catchment. $14 \mathrm{GW}$ wells have been placed across three contrasting landscape units in a $3.2 \mathrm{~km}^{2}$ experimental catchment in the Scottish Highlands. The observed water table fluctuations were characterised via statistical analysis, peak to peak lag time analysis (between GW and stream discharge response) and GW hysteresis response relative to streamflow.

Three hydropeodological units (peat, peaty gley and peaty podzol) could be differentiated through different storage-discharge relationships with lateral flow response thresholds varying among soil units. The steeper upslope area was characterized by shallow, freely draining podzols of limited storage capacity and, thus, more variable GW dynamics. Here, vertical flow dominated and larger recharge events are needed for the water table to overcome storage thresholds in order to rise into the soil and to connect with the lower hillslope area. The valley bottom comprises hydrologically more responsive soils with a large water storage capacity due to its highly organic content, and nearly constant seepage all year around and little recharge to depth. The temporal variability in GW response varied not only at an event scale, but also seasonally with much more noticeable and variable water table dynamics during the dryer seasons (summer/fall). Again, strong dependencies between temporal GW fluctuations and landscape characteristics (soil depth, hillslope topography, TWI) were evident. Topographic controls on the spatial organisation of GW dynamics were strongest during low flows (low initial GW levels) and small precipitation events. Limited storage capacity and extensive saturation due to increased rainfall inputs during wetter conditions weakened the topographic controls on the spatial organisation of GW dynamics.

\section{ACKOWLEDGEMENTS}

Funding was provided by the Leibniz Association (SAW- 2012-IGB 4167) within the International Leibniz Graduate School: Aquatic boundaries and linkages- Aqualink. We would like to thank the NRI staff for their help during field work. 


\section{REFERENCES}

Aishlin, P., \& McNamara, J. P. (2011). Bedrock infiltration and mountain block recharge accounting using chloride mass balance. Hydrological Processes, 25: 1934-1948. doi: 10.1002/hyp.7950

Ambroise, B. (2004). Variable "active" versus "contributing" areas or periods: a necessary distinction. Hydrological Processes, 18, 1149-1155. doi:10.1002/hyp. 5536

Anderson, M. G., \& Burt, T. P. (1978). The role of topography in controlling throughflow generation, Earth Surf. Processes Landforms, 3, 331-334. doi:10.1002/esp.3290030402

Asano, Y., Uchida, T., \& Ohte, N. (2002). Residence times and flow paths of water in steep unchannelled catchments, Tanakami, Japan, Journal of Hydrology, 261(1-4), 173-192, doi:10.1016/S0022-1694(02)00005-7

Bachmair, S., \& Weiler, M. (2012). Hillslope characteristics as controls of subsurface flow variability, Hydrology and Earth System Sciences, 16(10), 3699-3715, doi:10.5194/hess-16-3699-2012.

Bailey, S.W., Brousseau, P.A., McGuire, K.J., \& Ross, D.S. (2014). Influence of hillslope position and transient water table on soil development and carbon distribution in a steep, headwater catchment. Geoderma, 226-227:279-289. doi:10.1016/j.geoderma.2014.02.017

Batlle-Aguilar, J., Harrington, G. A., Leblanc, M., Welch, C. \& Cook, P. G. (2014). Chemistry of groundwater discharge inferred from longitudinal river sampling, Water Resource Research, 50, 1550-1568, doi:10.1002/ 2013WR013591

Birkel, C., Tetzlaff, D., Dunn, S.M., Soulsby, C. (2010). Towards simple dynamic process conceptualization in rainfall-runoff models using multi-criteria calibration and tracers in temperate, upland catchments. Hydrological Processes, 24: 260-275. doi: 10.1002/hyp.7478

Birkel, C., Tetzlaff, D., Dunn, S.M., Soulsby, C. (2011a). Using time domain and geographic source tracers to conceptualise streamflow generation processes in lumped rainfall-runoff models. Water Resources Research, 47: W02515. doi: 10.1029/2010WR009547

Birkel, C., Soulsby, C., \& Tetzlaff, D. (2011b). Modelling catchment-scale water storage dynamics: reconciling dynamic storagewith tracer-inferred passive storage. Hydrological Processes, 25:3924-3936. doi: 10.1002/hyp.8201

Birkel, C., Soulsby, C., \& Tetzlaff, D. (2014). Developing a consistent process-based conceptualization of catchment functioning using measurements of internal state variables, Water Resources Research, 50, 3481- 3501, doi:10.1002/2013WR014925

Birkel, C., Soulsby, C., \% Tetzlaff, D. (2015). Conceptual modelling to assess how the interplay of hydrological connectivity, catchment storage and tracer dynamics controls nonstationary water age estimates. Hydrological Processes, 29, 2956-2969. doi: 10.1002/hyp.10414

Blumstock, M., Tetzlaff, D., Malcolm, I.A., Nuetzmann, G., Soulsby, C. (2015). Baseflow dynamics: Multi-tracer surveys to assess variable groundwater contributions to montane streams under low flows. Journal of Hydrology, 527, 1021-1033. doi:10.1016/j.jhydrol.2015.05.019

Buttle, J.M., Dillon, P.J., \& Eerkes, G.R. (2004). Hydrologic coupling of slopes, riparian zones and streams: an example from the Canadian Shield. Journal of Hydrology, 287, 161-177. doi:10.1016/j.jhydrol.2003.09.022

Camporese, M., Penna, D., Borga, M., \& C. Paniconi (2014). A field and modeling study of nonlinear storage- discharge dynamics for an Alpine headwater catchment, Water Resources Research, 50, 806-822. doi:10.1002/ 2013WR013604 
Capell, R., Tetzlaff, D., Hartley, A. J., \&Soulsby, C. (2012). Linking metrics of hydrological function and transit times to landscape controls in a heterogeneous mesoscale catchment. Hydrological Processes, 26: 405-420. doi: 10.1002/hyp.8139

Caulfield, J., Chelliaha, M., Comte, J.C., Cassidy, R., \& Flynn, R. (2014). Integrating petrography, mineralogy and hydrochemistry to constrain the influence and distribution of groundwater contributions to baseflow in poorly productive aquifers: Insights from Gortinlieve catchment, Co. Donegal, NW Ireland. Science of The Total Environment, 500-501: 224-234. doi:10.1016/j.scitotenv.2014.08.105

Costelloe, J. F., Peterson, T. J., Halbert, K., Western, A. W., \& McDonnell, J. J. (2015). Groundwater surface mapping informs sources of catchment baseflow, Hydrology and Earth System Sciences, 19, 1599-1613, doi:10.5194/hess-19-1599-2015

Detty, J. M., \& McGuire, K. J. (2010). Threshold changes in storm runoff generation at a till-mantled headwater catchment, Water Resources Research, 46, W07525, doi:10.1029/2009WR008102

Freer, J., McDonnell, J.J., Beven, K.J., Peters, N.E., Burns, D.A., Hooper, R.P., \& Aulenbach, B. (2002). The role of bedrock topography on sub- surface storm flow. Water Resources Research, 38, 1269, doi: 1210.1029/2001WR000872

Frisbee, M. D., F. M. Phillips, A. R. Campbell, F. Liu, \& S. A. Sanchez (2011). Streamflow generation in a large, alpine watershed in the southern Rocky Mountains of Colorado: Is streamflow generation simply the aggregation of hillslope runoff responses? Water Resources Research, 47, W06512, doi:10.1029/2010WR009391

Fujimoto, M., Ohte, N., \& Tani, M. (2008). Effects of hillslope topography on hydrological responses in a weathered granite mountain, Japan: comparison of the runoff response between the valley-head and the side slope. Hydrological Processes, 22: 2581-2594. doi: 10.1002/hyp.6857

Gabrielli, C. P., McDonnell, J. J., \& Jarvis, W. T. (2012). The role of bedrock groundwater in rainfallrunoff response at hillslope and catchment scales, Journal of Hydrology, 450, 117-133. doi:10.1016/j.jhydrol.2012.05.023

Gannon, J. P., S. W. Bailey, \& K. J. McGuire (2014). Organizing groundwater regimes and response thresholds by soils: A framework for understanding runoff generation in a headwater catchment, Water Resources Research, 50, 8403-8419. doi:10.1002/ 2014WR015498

Geris, J., Tetzlaff, D., McDonnell, J. \& Soulsby, C. (2015). The relative role of soil type and tree cover on water storage and transmission in northern headwater catchments. Hydrol. Process., 29: 1844-1860. doi: 10.1002/hyp.10289.

Graham, C. B., Woods, R. A., \& McDonnell, J. J. (2010). Hillslope threshold response to rainfall: (1) A field based forensic approach, Journal of Hydrology, 393(1), 65-76, doi:10.1016/j.jhydrol.2009.12.015

Hannah, D.M., I. A., Malcolm, C.S., \& Youngson, A.F. (2008). A Comparison of Forest and Moorland Stream Microclimate, Heat Exchanges and Thermal Dynamics. Hydrological Processes, 22 (7): 919-40. doi:10.1002/hyp.7003

Haria, A. H., \& Shand, P. (2004). Evidence for deep sub-surface flow routing in forested upland Wales: implications for contaminant transport and stream flow generation. Hydrology and Earth System Sciences, 8, 334-344. doi:10.5194/hess-8-334-2004 
Haria, A. H., Shand, P., Soulsby, C., \& Noorduijn, S. (2013). Spatial delineation of groundwatersurface water interactions through intensive in-stream profiling. Hydrological Processes, 27: 628-634. doi: 10.1002/hyp.9551

Harman, C., \& Sivapalan, M. (2009). A similarity framework to as- sess controls on shallow subsurface flow dynamics in hillslopes, Water Resources Research, 45, W01417, doi:10.1029/2008wr007067

Haught, D. R. W., \& van Meerveld, H. J. (2011). Spatial variation in transient water table responses: differences between an upper and lower hillslope zone. Hydrological Processes, 25: 3866-3877. doi: 10.1002/hyp.8354

Heggenes, J., Bremset, G. \& Brabrand, Å. (2011). Groundwater, critical habitats, and behaviour of Atlantic salmon, brown trout and Arctic char in streams. - NINA Report 654, 28 pp.

Hopp, L., \& McDonnell, J. J. (2009). Connectivity at the hillslope scale: Identifying interactions between storm size, bedrock permeability, slope angle and soil depth, Journal of Hydrology., 376(3-4), 378-391, doi:10.1016/j. jhydrol.2009.07.047.

Johnson, R. H., (2009). The Influence of Shallow and Deep Ground-Water Discharge on StreamWater Quality in a Watershed with Historical Mining, Prospect Gulch, Colorado, USA. Presented at Securing the Future and $8^{\text {th }}$ ICARD, June 23-26, Skelleftea, Sweden.

Katsuyama, M., Fukushima, K., \& Tokuchi, N. (2008). Comparison of Rainfall-Runoff Characteristics in Forested Catchments Underlain by Granitic and Sedimentary Rock with Various Forest Age. Hydrological Research Letters, Vol. 2, pp.14-17. doi: 10.3178/HRL.2.14

Kay, A.L., Crooks, S.M., Davies, H.N., Reynard, N.S., 2014. Probabilistic impacts of climate change on flood frequency using response surfaces II: Scotland. Regional Environmental Change. 14 (3), 1243-1255. doi:10.1007/s10113-013-0564-x.

Koch, K., Wenninger, J., Uhlenbrook, S., \& Bonell, M. (2009). Joint interpretation of hydrological and geophysical data: electrical resistivity tomography results from a process hydrological research site in the Black Forest Mountains, Germany. Hydrological Processes, 23: 1501-1513. doi: 10.1002/hyp.7275

Laudon, H., Sjoblom, V., Buffam, I., Seibert, J., Morth, M. (2007). The role of catchment scale and landscape characteristics for runoff generation of boreal streams. Journal of Hydrology, 344, pp. 198-209. doi:10.1016/j.jhydrol.2007.07.010

Malcolm, I. A., Soulsby, C., Youngson, A. F., Hannah, D. M., McLaren, I. S., \& Thorne, A. (2004). Hydrological influences on hyporheic water quality: implications for salmonid survival. Hydrological Processes, 18, 1543-1560. doi: 10.1002/hyp.1405

Malcolm, I.A, Soulsby, C., \& Youngson, A.F. (2006). High frequency logging technologies reveal state dependence of hyporheic process dynamics: implications for hydroecology. Hydrological Processes, 20: 615-622. doi: 10.1002/hyp.6107

McGlynn, B.L., McDonnell, J.J., Seibert, J., \& Kendall, C. (2004). Scale effects on headwater catchment runoff timing, flow sources, and groundwater-streamflow relations. Water Resources Research, 40, W07504. doi:10.1029/ 2003WR002494

McGuire, K. J., \& McDonnell, J. J. (2010). Hydrological connectivity of hillslopes and streams: Characteristic time scales and nonlinearities, Water Resources Research, 46, W10543. doi:10.1029/2010WR009341 
McMillan, H. K., \& Srinivasan, M. S. (2015). Characteristics and controls of variability in soil moisture and groundwater in a headwater catchment, Hydrology and Earth System Sciences, 19, 17671786, doi:10.5194/hess-19-1767-2015, 2015

Neal, C., Hill, T., Hill, S., \& Reynolds, B. (1997). Acid neutralizing capacity measurements in surface waters and groundwaters in the upper Severn, Plynlimon: from hydrograph splitting to water flow pathways. Hydrology and Earth System Sciences, 3: 687-696. doi:10.5194/hess-1-6871997

Nippgen, F., McGlynn, B. L., \& Emanuel, R. E. (2015). The spatial and temporal evolution of contributing areas, Water Resources Research, 51, doi:10.1002/2014WR016719

Orr, H.G., Carling, P.A., (2006). Hydro-climatic and land use changes in the River Lune catchment, North West England, implications for catchment management. River Research and Applications. 22 (2), 239-255. http://dx.doi.org/10.1002/rra.908.

Penna, D., Mantese, N., Hopp, L., Dalla Fontana, G., \& Borga, M. (2015). Spatio-temporal variability of piezometric response on two steep alpine hillslopes, Hydrological Processes, 29, 198-211, doi: 10.1002/hyp.10140

Price, M. F., \& Egan, P. A. (2014) Policy Brief: Our global water towers: ensuring ecosystem services from mountains under climate change. UNESCO

R Development Core Team, 2009. R: A Language and Environment for Statistical Computing. R Foundation for Statistical Computing, Vienna, Austria. ISBN 3- 900051-07-0. <http://www.Rproject.org>.

Rinderer, M., van Meerveld, H. J., \& Seibert, J. (2014). Topographic controls on shallow groundwater levels in a steep, prealpine catchment: When are the TWI assumptions valid? Water Resources Research, 50, 6067-6080, doi:10.1002/2013WR015009

Rodgers, P., Soulsby, C., Petry, J.,Malcolm, I., Gibbins, C., \& Dunn, S. (2004). Groundwater-surfacewater interactions in a braided river: a tracer-based assessment. Hydrological Processes, 18: 1315-32. doi: 10.1002/hyp.1404

Seibert, J., Bishop, K., Rodhe, A., \& McDonnell, J. J. (2003). Groundwater dynamics along a hillslope: A test of the steady state hypothesis, Water Resources Research, 39(1), 1014. doi:10.1029/2002WR001404

Shaw, G. D., Conklin, M. H., Nimz, G. J., \& Liu, F., (2014). Ground water and surface water flow to the Merced River, Yosemite Valley, California: $36 \mathrm{Cl}$ and $\mathrm{Cl} 2$ evidence, Water Resources Research, 50, 1943-1959, doi:10.1002/ 2013WR014222.

Smith, R. S., Moore, R. D., Weiler, M., \& Jost, G. (2014). Spatial controls on groundwater response dynamics in a snowmelt-dominated montane catchment, Hydrolgy and Earth System Sciences, 18, 1835-1856, doi:10.5194/hess-18-1835-2014

Soulsby, C., Chen, M., Ferrier, R. C., Helliwell, R. C., Jenkins, A. \& Harriman, R. (1998). Hydrogeochemistry of shallow groundwater in an upland Scottish catchment. Hydrological Processes, 12: 1111-1127. doi: 10.1002/(SICI)1099-1085(19980615)12:7<1111::AIDHYP633>3.0.CO;2-2

Soulsby, C., Malcolm, R., Helliwell, R., Ferrier, R. C., \& Jenkins, A. (2000). Isotope hydrology of the Allt a' Mharcaidh catchment, Cairngorms, Scotland: implications for hydrological pathways and residence times. Hydrological Processes, 14: 747-762. doi: 10.1002/(SICI)10991085(200003)14:4<747::AID-HYP970>3.0.CO;2-0 
Soulsby, C., Malcolm, I.A., Youngson, A.F., Tetzlaff, D., Gibbins, C.N. \& Hannah, D.M. (2005).

Groundwater - surface water interactions in upland Scottish rivers: hydrological, hydrochemical and ecological implications. Scottish Journal of Geology, 41-1, 39-49. doi: 10.1144/sjg41010039

Soulsby, C., Tetzlaff, D., van den Bedem, N., Malcolm, I. A., Bacon, P. J., \& Youngson, A. F. (2007). Inferring groundwater influences on surface water in montane catchments from hydrochemical surveys of springs and streamwaters, J. Hydrol., 333, 199-213. doi:10.1016/j.jhydrol.2006.08.016, 2007

Soulsby, C., Neal, C., Laudon, H., Burns, D.A., Merot, P., Bonell, M., Dunn, S.M., \& Tetzlaff, D. (2008) Catchment data for process conceptualization: simply not enough? Hydrological Processes 22 , 2057-2061.

Soulsby, C., Birkel, C., Geris, J., Dick, J., Tunaley, C., \& Tetzlaff D. (2015). Stream water age distributions controlled by storage dynamics and nonlinear hydrologic connectivity: Modelling with high-resolution isotope data, Water Resour. Res., 51, 7759-7776, doi:10.1002/2015WR017888.

Soulsby, C., Bradford, J., Dick, J., McNamara, J., Geris, J., Lessels, J., Blumstock, M., \& Tetzlaff, D. (in review). Using geophysical surveys to test tracer-based storage estimates in headwater catchments. Hydrological Processes.

Tetzlaff, D., Soulsby, C., Waldron, S., Malcolm, I.A., Bacon, P.J., Dunn, S.M., Lilly, A., \& Youngson, A.F., (2007). Conceptualization of Runoff Processes Using a Geographical Information System and Tracers in a Nested Mesoscale Catchment. Hydrological Processes, 21 (10): 1289-1307. doi: 10.1002/hyp.6309

Tetzlaff, D., \& Soulsby, C. (2008).Sources of baseflow in larger catchments -Using tracers to develop a holistic understanding of runoff generation. Journal of Hydrology, 359: 287-302. doi: 10.1016/j.jhydrol.2008.07.008.

Tetzlaff, D., Birkel, C., Dick, J., Geris, J., \& Soulsby, C. (2014). Storage dynamics in hydropedological units control hillslope connectivity, runoff generation, and the evolution of catchment transit time distributions, Water Resources Research, 50, 969-985, doi: 10.1002/2013WR014147

Tromp-van Meerveld, H.J., \& McDonnell, J.J. (2006a). Threshold relations in subsurface stormflow: 1. A 147-storm analysis of the Panola hillslope. Water Resources Research, 42: 11. doi: 10.1029/2004wr003778

Tromp-van Meerveld, H.J., \& McDonnell, J.J. (2006b). Threshold relations in subsurface stormflow: 2. The fill and spill hypothesis. Water Resources Research, 42: W02411. doi: 10.1029/WR003800

Uhlenbrook, S., Frey, M., Leibundgut, C., \& Maloszewski, P. (2002). Hydrograph separations in a mesoscale mountainous basin at event and seasonal timescales, Water Resources Research, 38(6), doi:10.1029/2001WR000938, 2002

UKCP09. 2009. "UK Climate Projections."

von Freyberg, J., Radny, D., Gall, H.E., \& Schirmer, M. (2014). Implications of hydrologic connectivity between hillslopes and riparian zones on streamflow composition. Journal of Contaminant Hydrology, 169, pp. 62-74, doi:10.1016/j.jconhyd.2014.07.005

Weiler, M., McDonnell, J.J., Tromp-van Meerveld, H.J., \& Uchida, T. (2005). Subsurface stormflow. Encyclopedia of Hydrological Sciences,vol. 3, AndersonM(ed). John Wiley\&Sons,Ltd.:Hoboken, NJ, USA; 1719-1732. 
Winter, Thomas C., (2007). The Role of Ground Water in Generating Streamflow in Headwater Areas and in Maintaining Base Flow. Journal of the American Water Resources Association (JAWRA), 43(1):15-25. DOI: 10.1111/j.1752-1688.2007.00003.x

Vidon, P.G.F., \& Hill. A.R. (2004). Landscape controls on the hydrology of stream riparian zones. Journal of Hydrology. 292, pp. 210-228. doi:10.1016/j.jhydrol.2004.01.005 


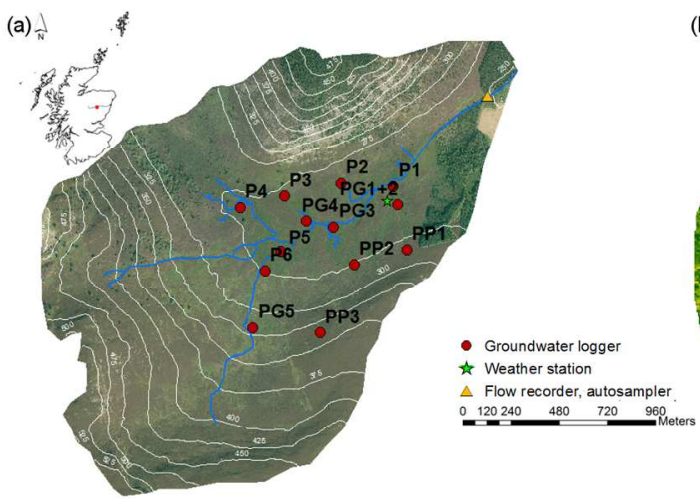

(c)

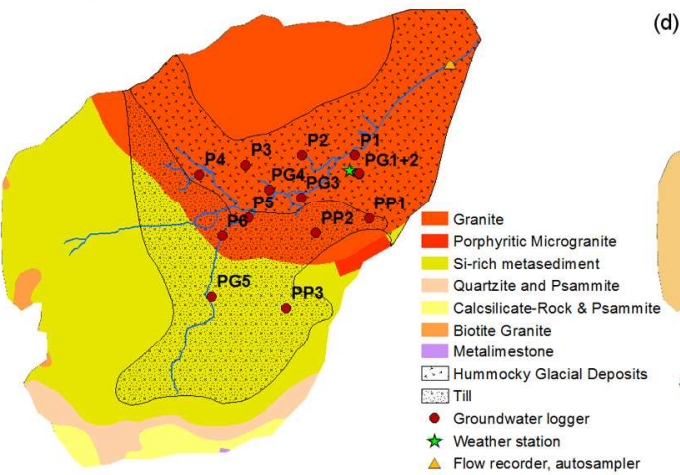

(d)

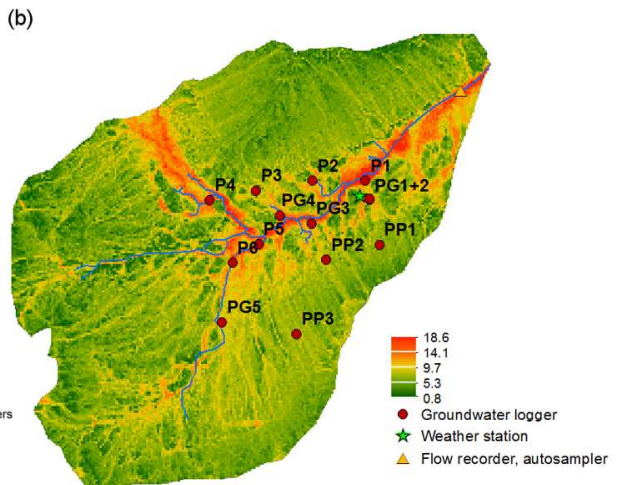

(b)

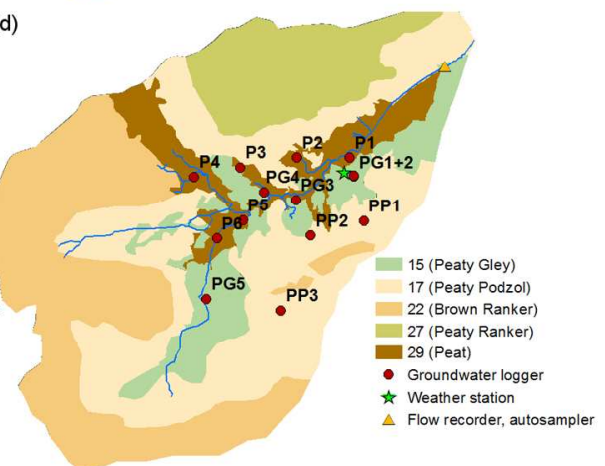

Figure 1: Bruntland Burn catchment (a) topography, showing location of the weather station, flow recorder and groundwater logger locations located in P= Peat, PP= Peaty Podzol and PG= Peaty Gley soil; (b) LIDAR based topographic Wetness Index (TWI); (c) bedrock geology and superficial geology classification and (d) distribution of main soil classes. $635 \times 476 \mathrm{~mm}(72 \times 72 \mathrm{DPI})$ 


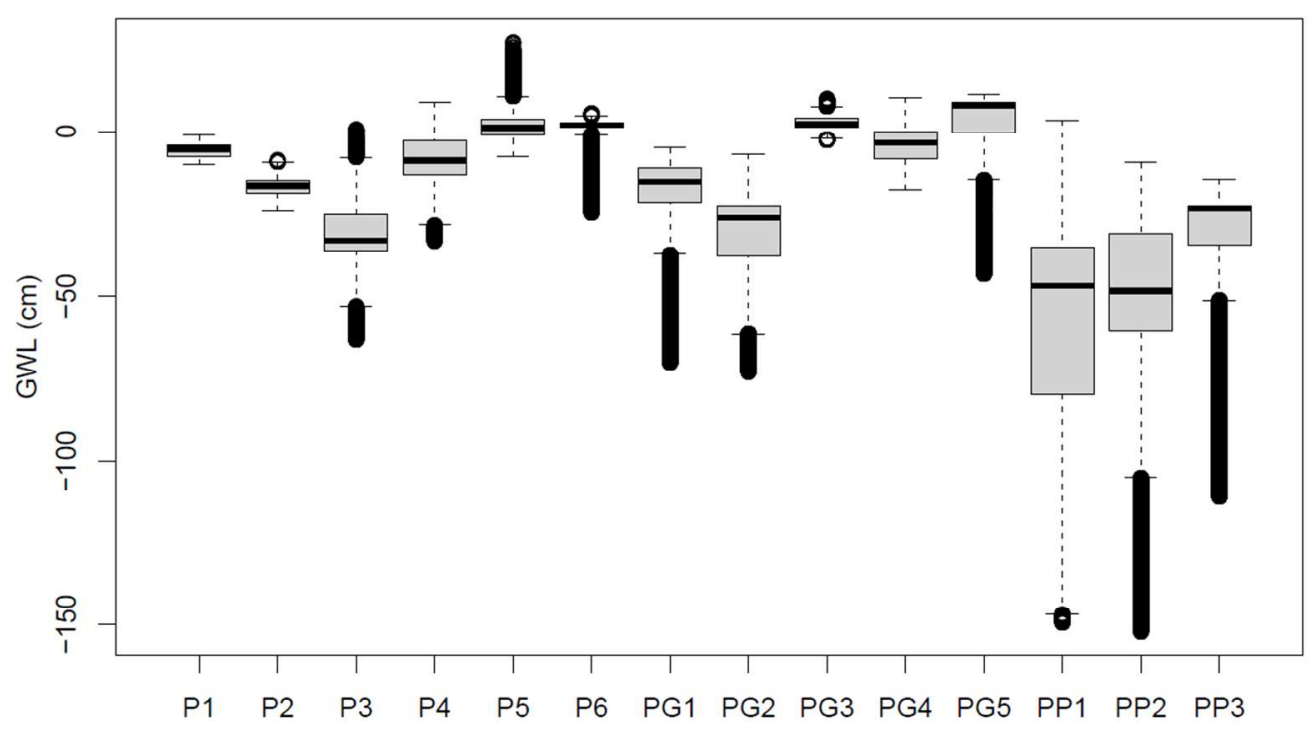

Figure 2: Ranges in groundwater levels between 1st of June 2013 and 31st of May 2014. The boxes determine the 25th and 75th percentile, the whiskers indicate the 10th and 90th percentile and the horizontal line within the box indicates the median. $300 \times 164 \mathrm{~mm}(96 \times 96 \mathrm{DPI})$ 

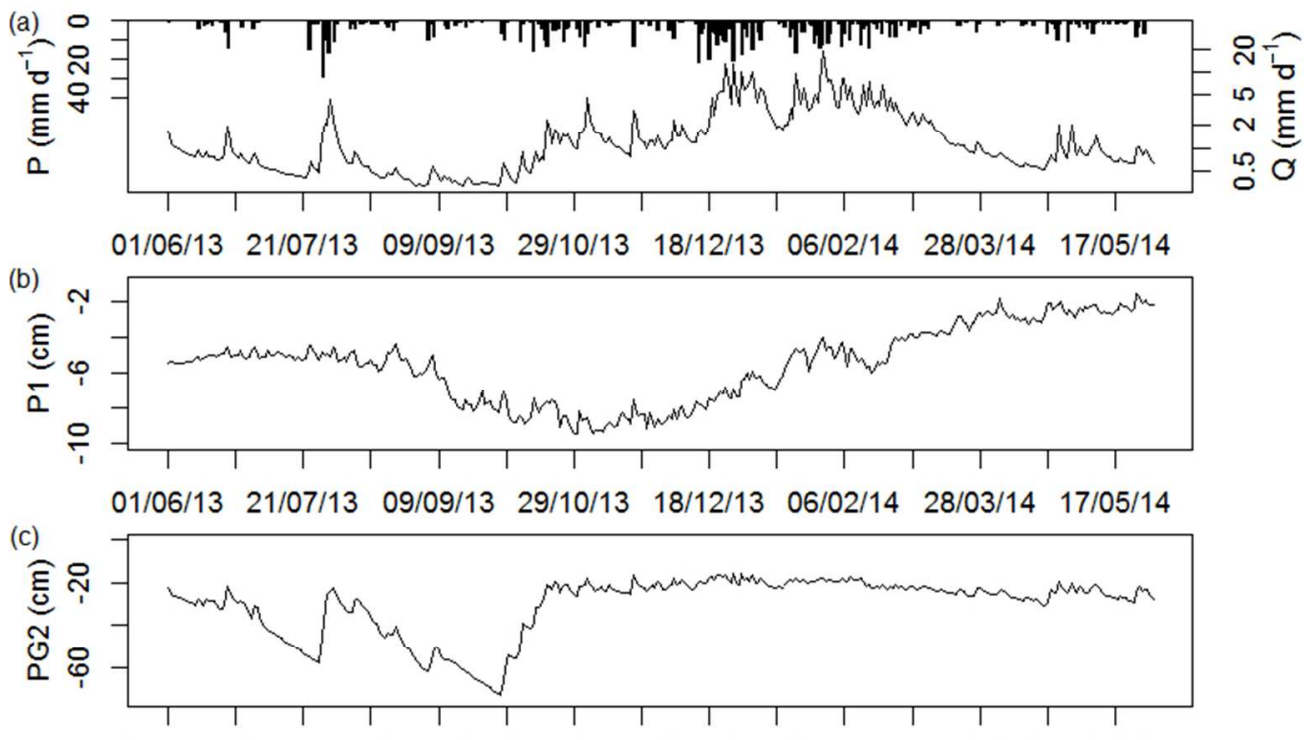

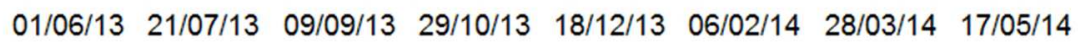

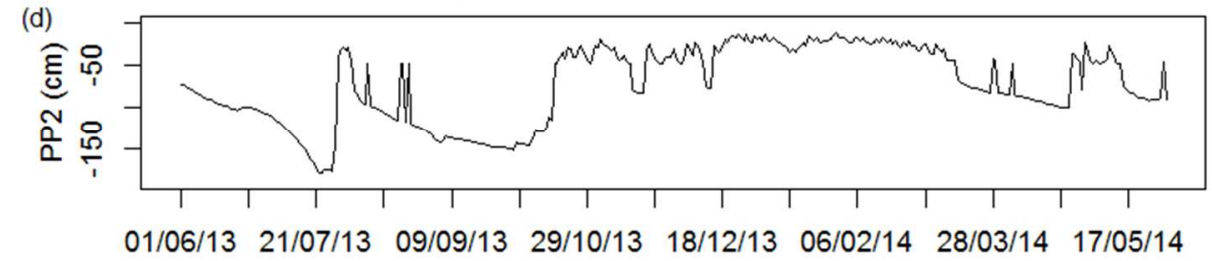

Figure 3: (a) Precipitation and discharge; and groundwater level dynamics for a site in (b) Peat, (c) Peaty Gley and (d) Peaty Podzol between 1st of June 2013 and 31st of May 2014. $214 \times 169 \mathrm{~mm}(96 \times 96 \mathrm{DPI})$ 

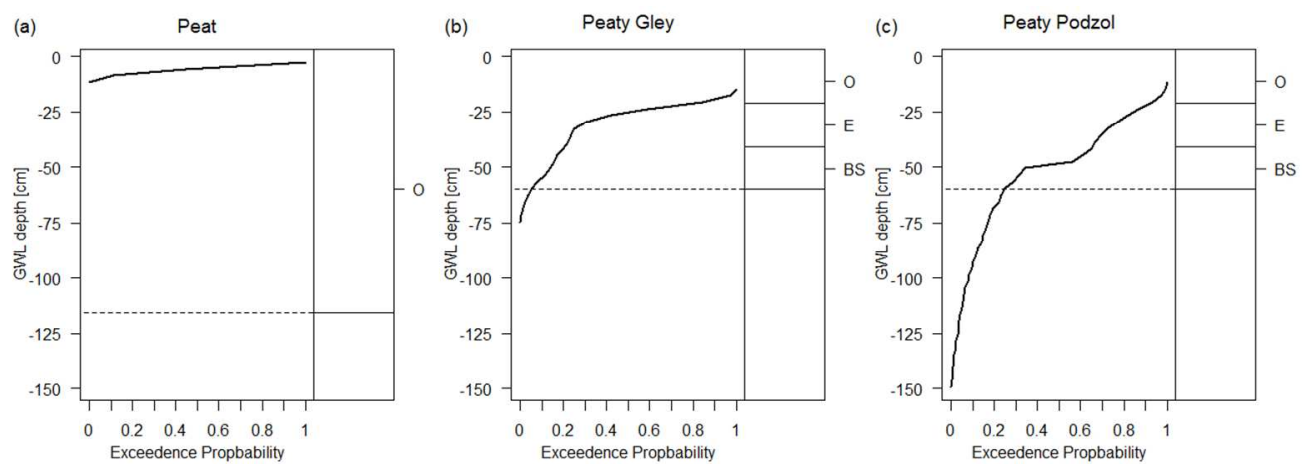

Figure 4: Empirical cumulative density functions for three groundwater level dynamics for a site in (a) Peat, (b) Peaty Gley and (c) Peaty Podzol between 1st of June 2013 and 31st of May 2014 with soil horizons shown to the right. Dashed line represents the soil-drift interface.

\section{$458 \times 165 \mathrm{~mm}(72 \times 72 \mathrm{DPI})$}



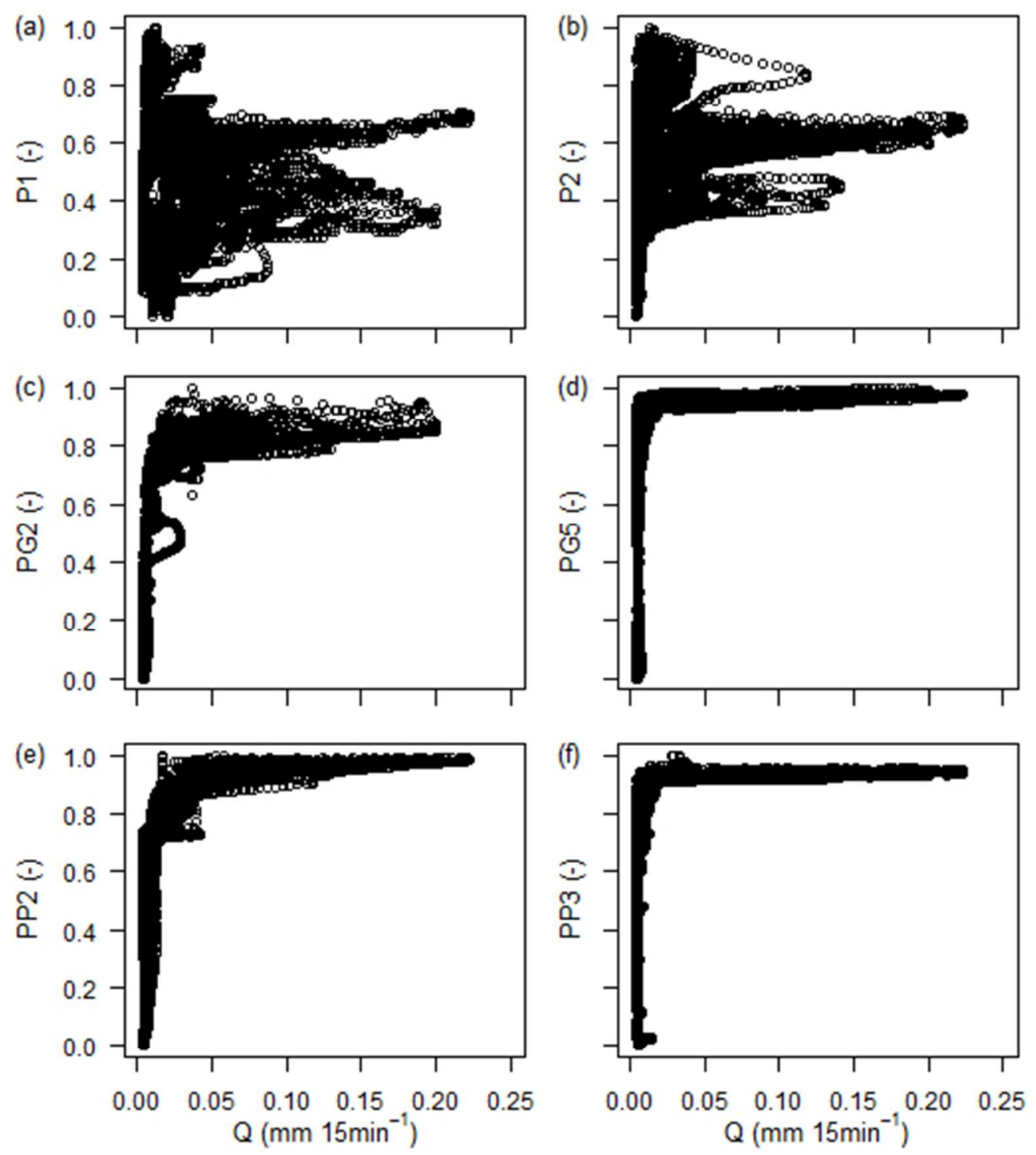

Figure 5: Normalized groundwater table responses in (a)-(b) Peat, (c)-(d) Peaty Gley and (e)-(f) Peaty Podzol versus discharge between 1st of June 2013 and 31st of May 2014. $183 \times 205 \mathrm{~mm}(72 \times 72 \mathrm{DPI})$ 

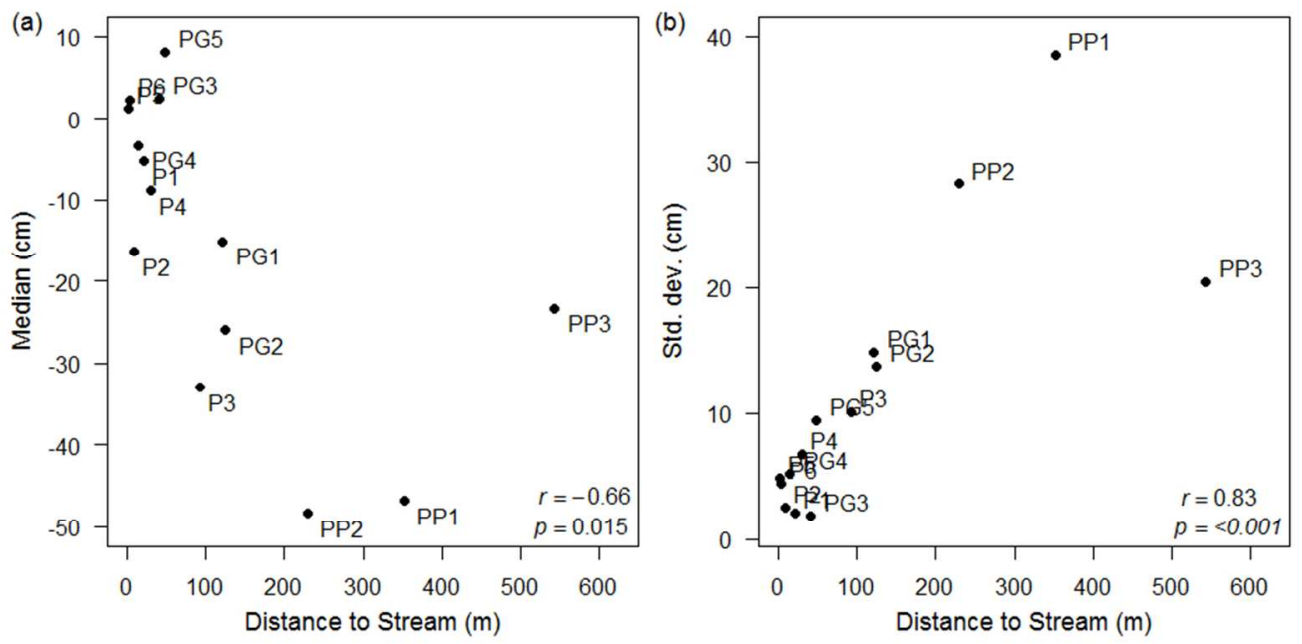

Figure 6: (a) Median and (b) standard deviation of groundwater table depth versus distance to stream. $328 \times 167 \mathrm{~mm}(72 \times 72 \mathrm{DPI})$ 

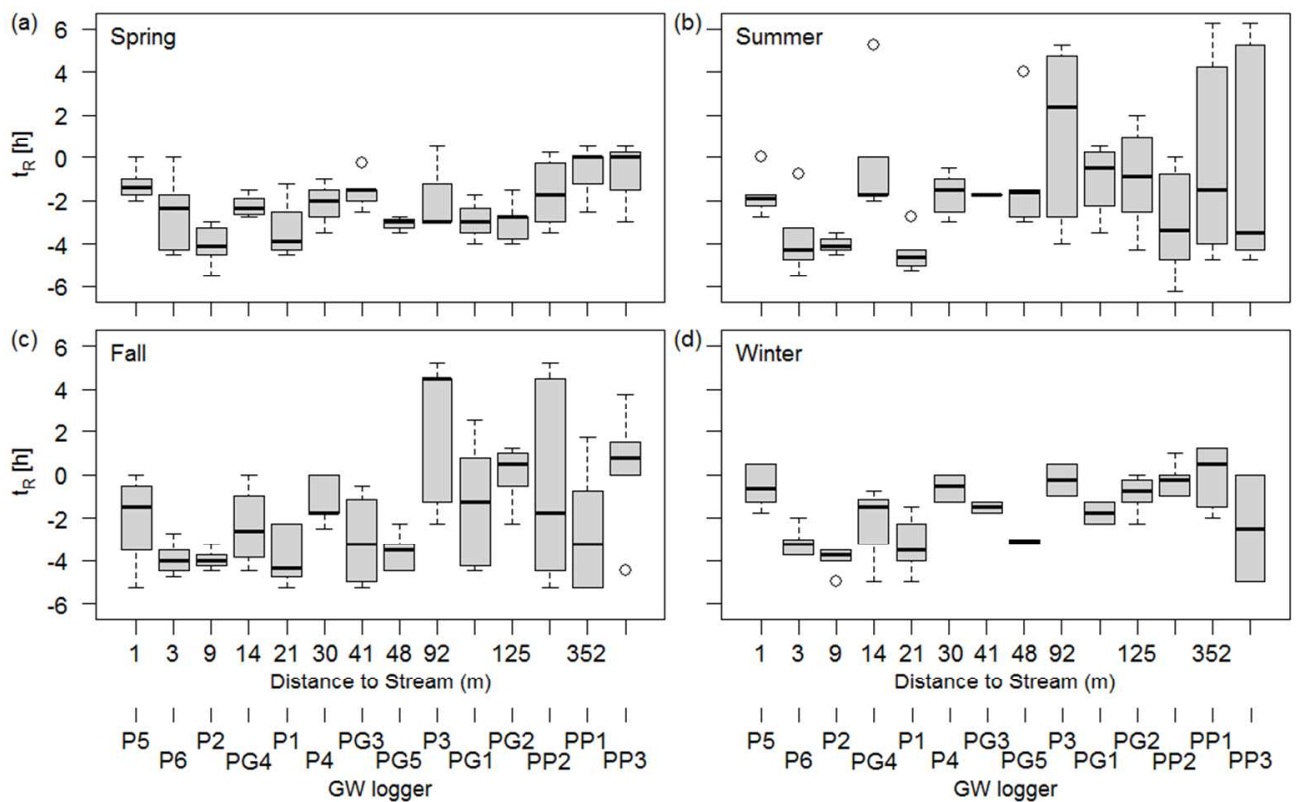

Figure 7: Peak-to-peak lag time analysis between groundwater table peak and discharge peak for all loggers with changing distance to stream occurring in (a) Spring, (b) Summer, (c) Fall and (d) Winter. Negative lag times indicate a GW level response to precipitation prior discharge. $379 \times 234 \mathrm{~mm}(72 \times 72 \mathrm{DPI})$ 
(a)

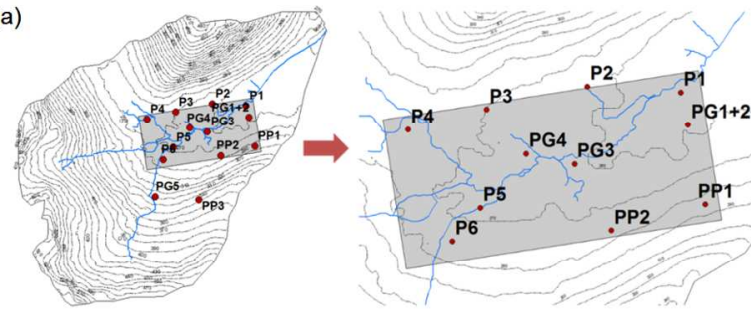

(b)

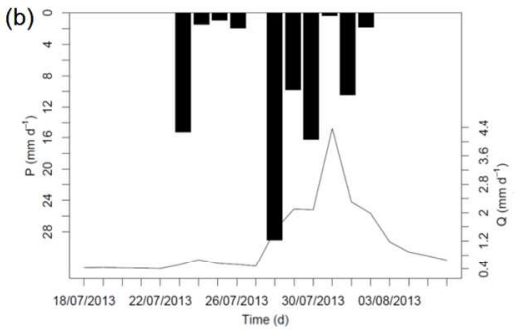

(c)
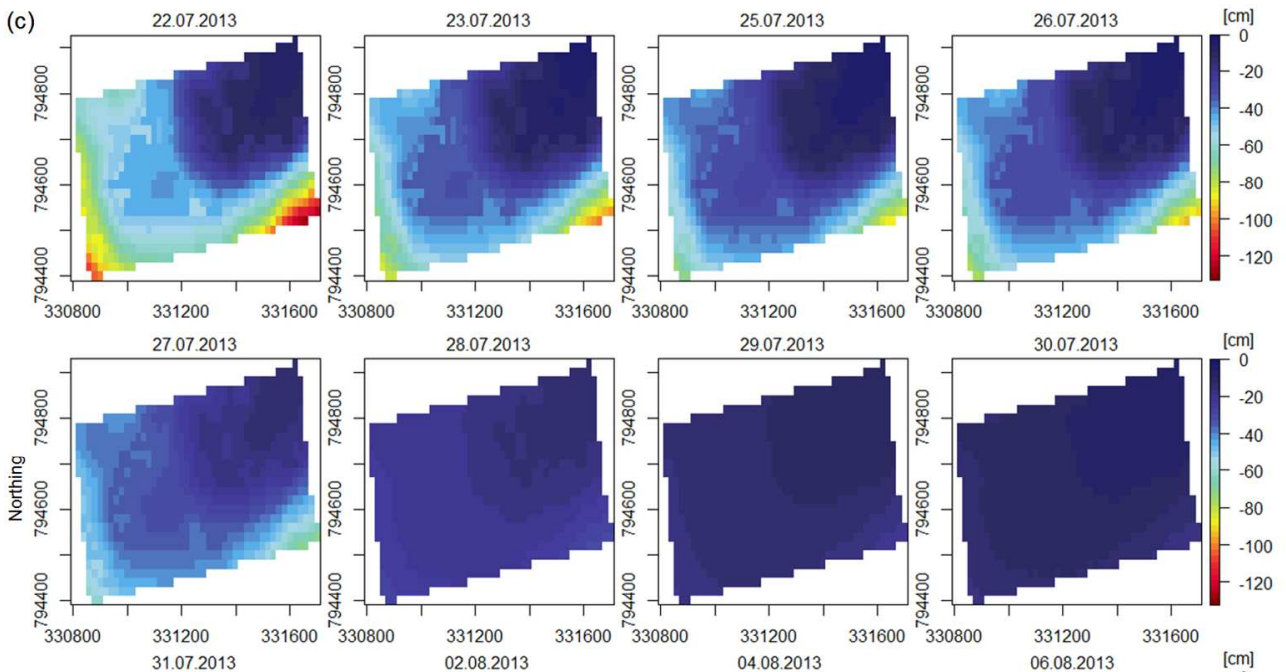

04.08 .2013

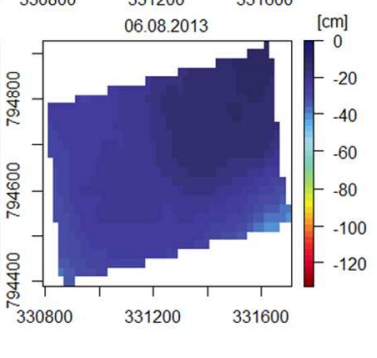

Figure 8: GW level dynamics during a rainfall event after dry antecedent conditions: Rainfall event starts at the 23 rd of July ' 13 and peaks at the 28th of July ' 13 while discharge peaks at the 29th of July ' 13 . a) shows the area used for interpolation, b) is precipitation and discharge for the considered time period and c) are the spatially distributed GW level dynamics.

$$
564 \times 599 \mathrm{~mm}(72 \times 72 \text { DPI) }
$$


(a)

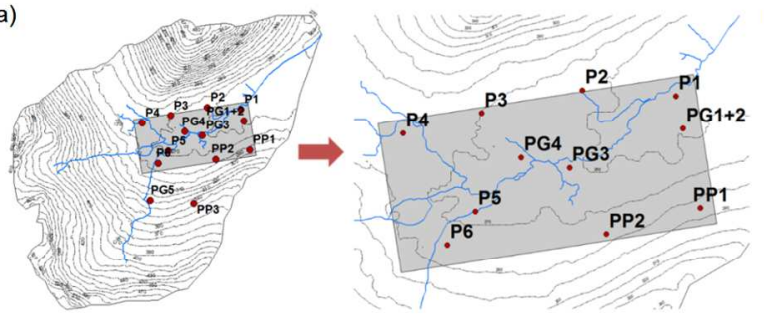

(b)

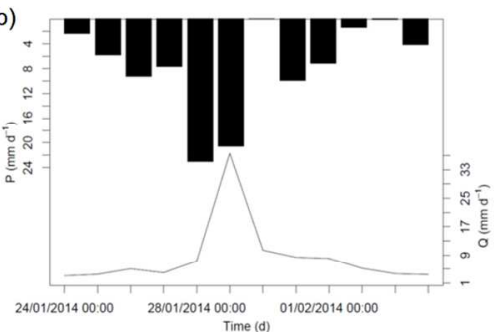

(c)
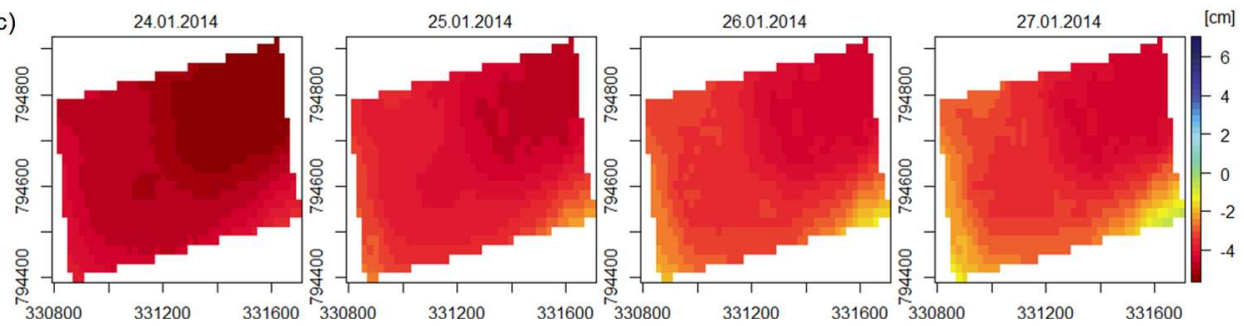

28.01.2014 29.01.2014 331200
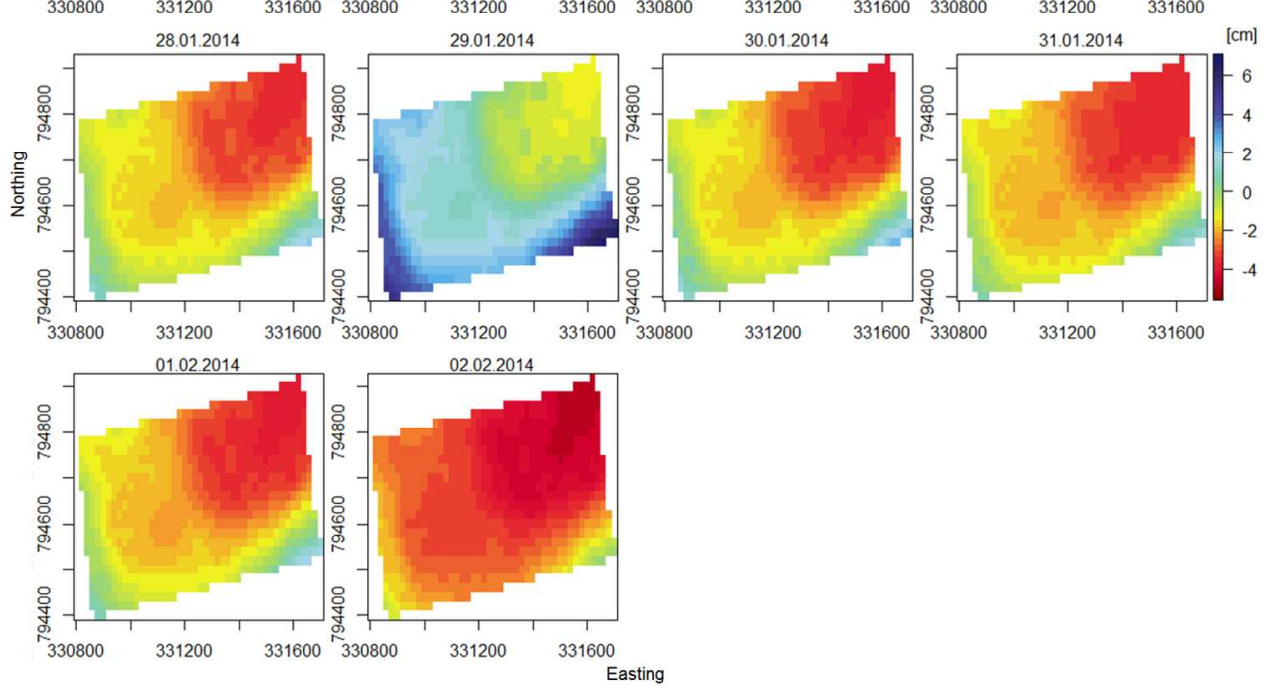

Figure 9: GW level dynamics during a rainfall event after wet antecedent conditions. Rainfall event starts at the 24th of Jan. ' 13 and peaks at the 28th of Jan. '14 while discharge peaks at the 29th of Jan. '14. a) shows the area used for interpolation, b) is precipitation and discharge for the considered time period and c) are the spatially distributed GW level dynamics. $564 \times 599 \mathrm{~mm}(72 \times 72 \mathrm{DPI})$ 

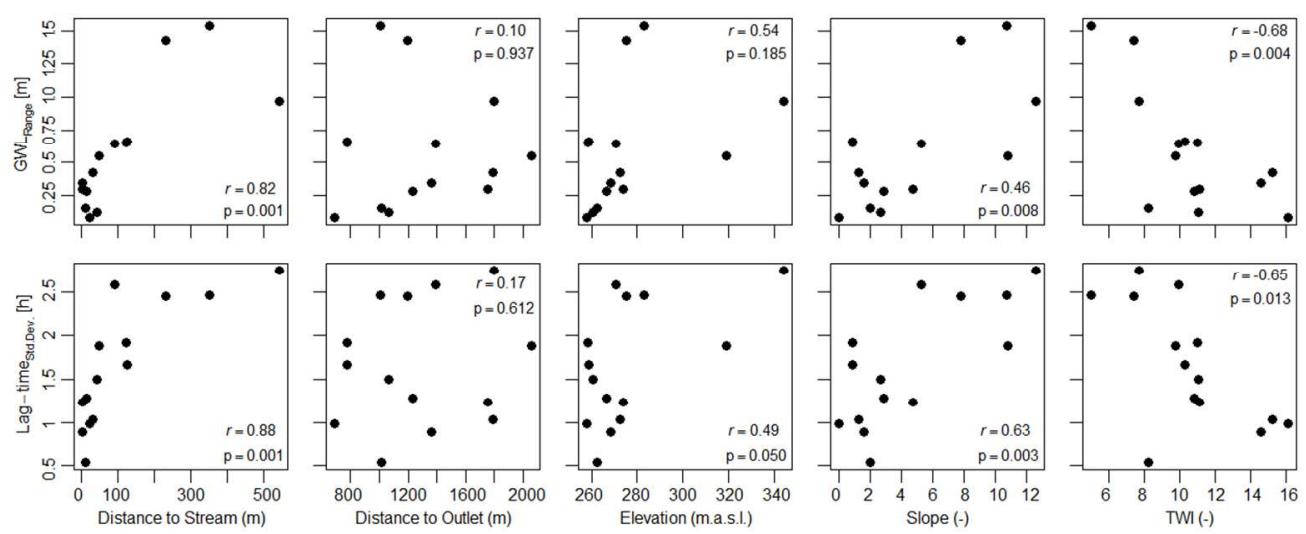

Figure 10: Groundwater dynamic variables (GWL range and lag time) against landscape characteristics. Correlations were not statistically significant between distance to stream with both GWLRange and tR, Std.Dev. and between elevation and GWLRange.

$440 \times 176 \mathrm{~mm}(72 \times 72 \mathrm{DPI})$ 


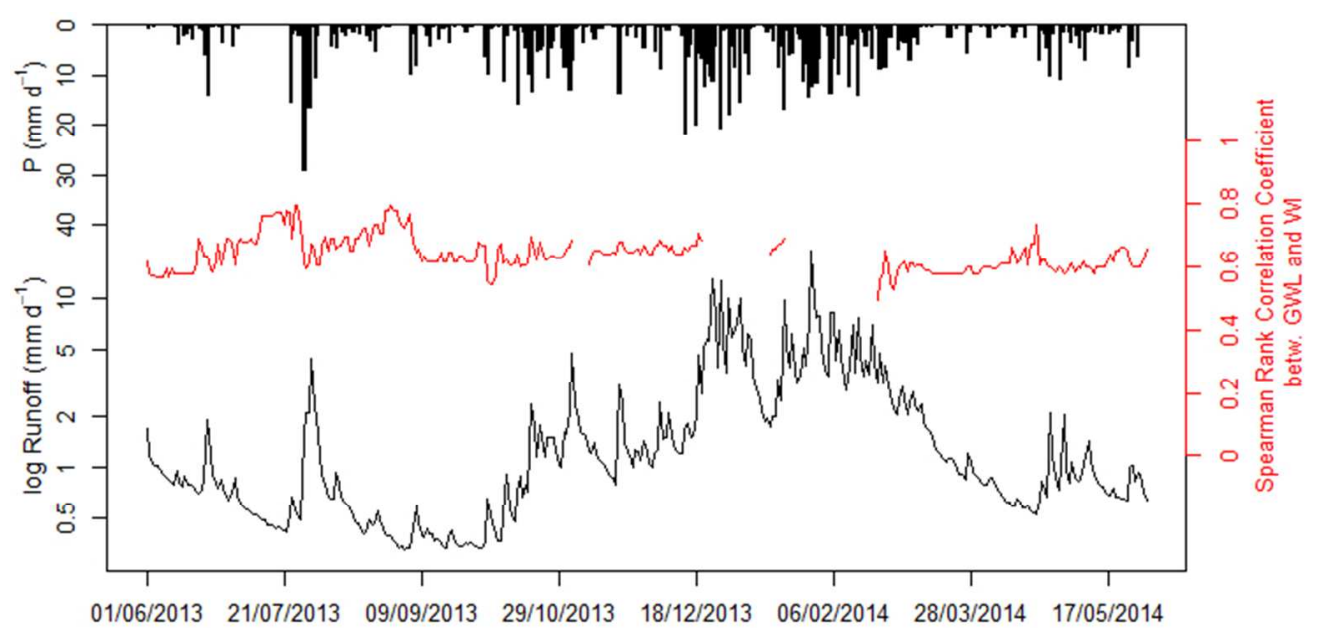

Figure 11: Precipitation, discharge and Spearman Rank Correlation Coefficient between groundwater level (GWL) at 14 locations and the topographic Wetness Index (WI). Correlation coefficients are significant with $\mathrm{p}<0.1$.

$261 \times 123 \mathrm{~mm}(72 \times 72 \mathrm{DPI})$ 
Figure 12: Dendrogram of the hierarchical cluster analysis based on wetness index, distance to stream and to outlet, elevation, slope, GW level median, GW level standard deviation, range of the GW level, median and standard deviation of the lag times of each logger. $186 \times 87 \mathrm{~mm}(150 \times 150 \mathrm{DPI})$ 


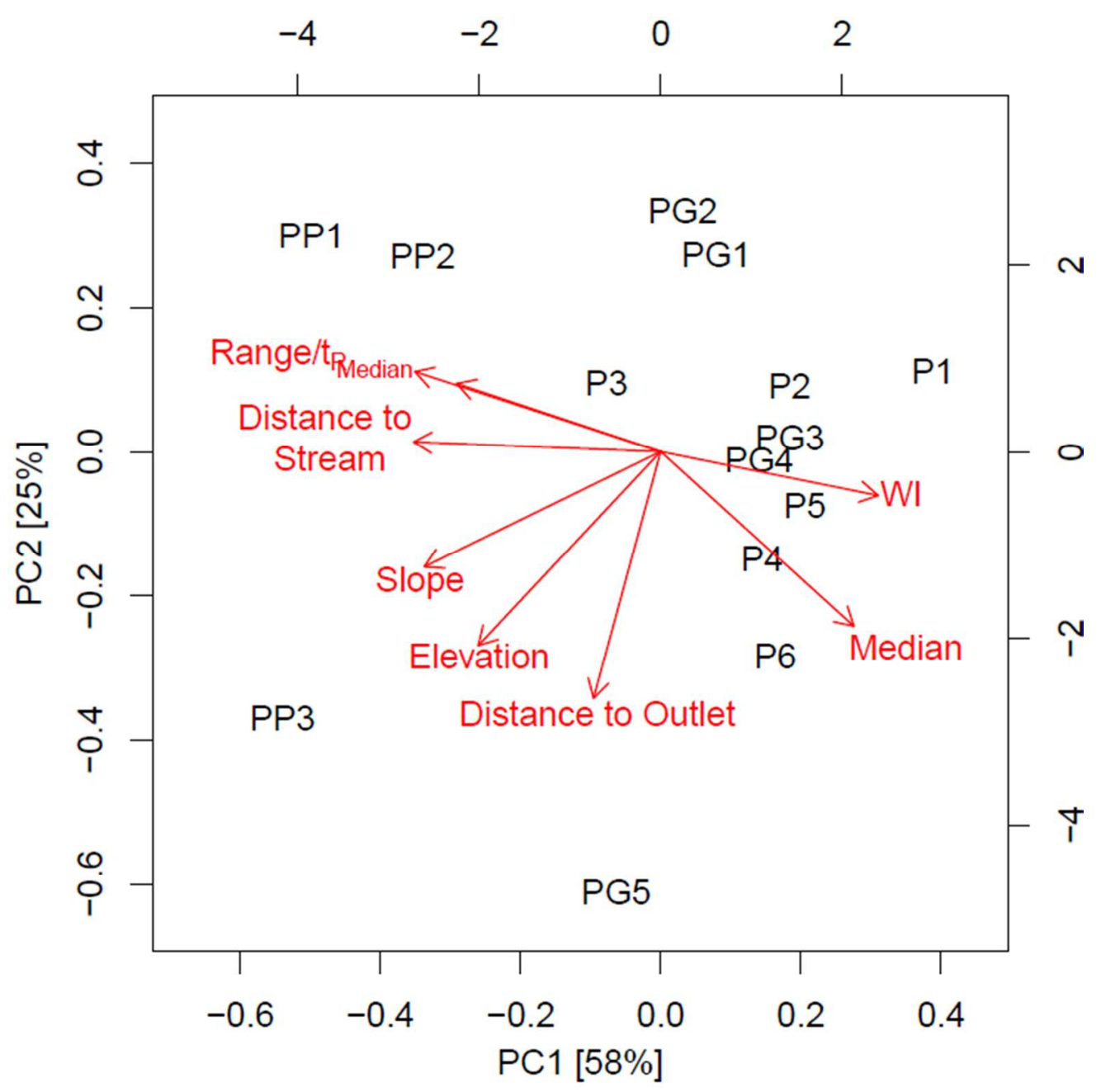

Figure 13: PCA of catchment and groundwater dynamic characteristics at 14 groundwater logger locations as biplot. The first two principal components explain $83 \%$ of the total variance. $192 \times 192 \mathrm{~mm}(96 \times 96 \mathrm{DPI})$ 
(a)

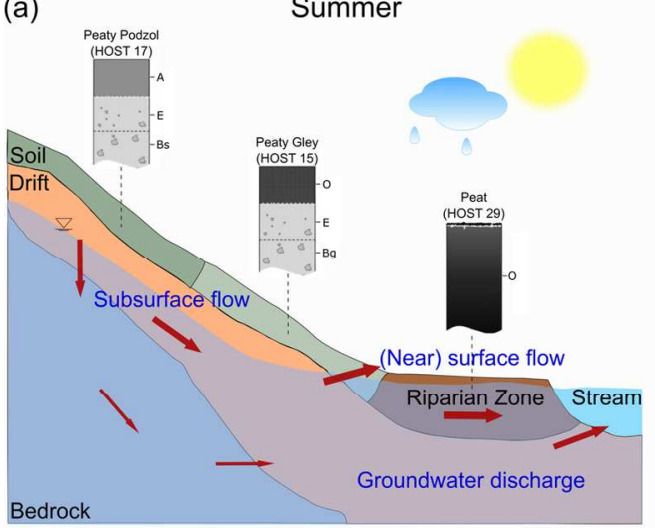

(b) Winter

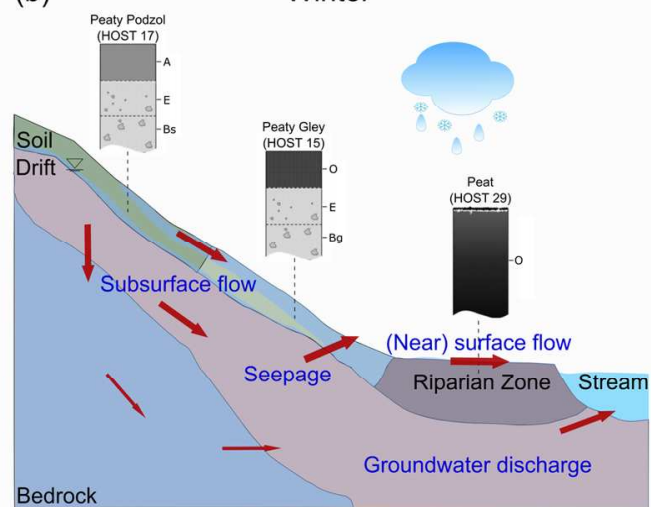

Figure 14: Conceptual scheme showing groundwater flowpaths along a hillslope transect in the Bruntland Burn during wet (a) and dry (b) conditions. Red arrows indicate groundwater flowpaths into the stream. $151 \times 63 \mathrm{~mm}(300 \times 300 \mathrm{DPI})$ 
Table 1: Catchment characteristics for the Bruntland Burn catchment ( ${ }^{*}$ land that has been drained and possibly fertilized for agricultural purposes)

\begin{tabular}{lll}
\hline Area $\left[\mathrm{km}^{2}\right]$ & & 3.2 \\
Soil & Brown Ranker & 30.7 \\
type [\%] & Peaty Podzol & 35.6 \\
& Peat & 9.6 \\
& Peaty Gley & 11.9 \\
& Peaty Ranker & 12.2 \\
Geology & Granite & 45.3 \\
type [\%] & Psammite \& semipelite & 46.9 \\
& Biotite Granite & 0.6 \\
& Quartzite and psammite & 4.0 \\
& Calcsilicate-rock \& psammite & 2.6 \\
& Metalimestone & 0.02 \\
& Porphyritic Microgranite & 0.6 \\
Vegetation & Moorland & 59.7 \\
type [\%] & Rock/Scree & 22.7 \\
& Blanket Bog & 5.9 \\
& Woodland & 11.1 \\
& Improved Land* & 0.5 \\
& Grassland & 0.2
\end{tabular}


Table 2: Landscape and shallow groundwater characteristics for each logger in the Bruntland Burn catchment

\begin{tabular}{|c|c|c|c|c|c|c|c|c|c|c|c|c|c|}
\hline $\begin{array}{l}\text { Logger } \\
\text { Name }\end{array}$ & $\begin{array}{l}\text { Elevation } \\
\text { [m.a.s.I.] }\end{array}$ & $\begin{array}{l}\text { Distance to } \\
\text { Stream }[\mathrm{m}]\end{array}$ & $\begin{array}{l}\text { Distance to } \\
\text { Outlet [m] }\end{array}$ & $\begin{array}{l}\text { Slope } \\
{\left[{ }^{\circ}\right]}\end{array}$ & $\begin{array}{l}\mathrm{t}_{\mathrm{R}, \text { Median }} \\
{[\mathrm{h}]^{1}}\end{array}$ & $\begin{array}{c}\mathrm{t}_{\mathrm{R}, \text { Std.Dev }} \\
{[\mathrm{h}]^{1}}\end{array}$ & $\begin{array}{l}\text { GW level } \\
{[\mathrm{cm}]^{2}}\end{array}$ & $\begin{array}{l}\text { GW level Median } \\
{[\mathrm{cm}]^{2}}\end{array}$ & $\begin{array}{l}\text { GW level }\left.\right|_{\text {std.Dev. }} \\
{[\mathrm{cm}]^{2}}\end{array}$ & $\begin{array}{l}\text { GW level }\left.\right|_{\text {Range }} \\
{[\mathrm{cm}]^{2}}\end{array}$ & $\begin{array}{l}\text { TWI } \\
{[-]^{3}}\end{array}$ & Soil type & Geology \\
\hline P1 & 258 & 21 & 686 & 0.0 & -4.25 & 1.0 & -5.5 & -5.3 & 2.1 & 8.8 & 16.2 & Peat & Granite \\
\hline P2 & 263 & 9 & 1015 & 2.0 & -4.0 & 0.5 & -16.6 & -16.4 & 2.5 & 15.3 & 8.3 & Peat & Granite \\
\hline P3 & 271 & 92 & 1389 & 5.3 & -1.0 & 2.6 & -30.5 & -32.9 & 10.1 & 64.2 & 10.0 & Peat & Granite \\
\hline P4 & 273 & 30 & 1788 & 1.3 & -1.1 & 1.0 & -8.5 & -8.8 & 6.8 & 42.1 & 15.3 & Peat & Granite \\
\hline P5 & 269 & 1 & 1360 & 1.6 & -1.5 & 0.9 & 2.0 & 1.3 & 4.8 & 34.9 & 14.6 & Peat & Granite \\
\hline P6 & 274 & 3 & 1753 & 4.7 & -3.5 & 1.2 & 0.5 & 2.3 & 4.5 & 30.0 & 11.1 & Peat & Granite \\
\hline PG1 & 259 & 121 & 775 & 0.9 & -1.5 & 1.9 & -20.8 & -15.1 & 14.9 & 65.2 & 11.0 & Peaty Gley & Granite \\
\hline PG2 & 259 & 125 & 779 & 0.9 & -1.3 & 1.7 & -31.7 & -26.0 & 13.7 & 66.1 & 10.3 & Peaty Gley & Granite \\
\hline PG3 & 261 & 41 & 1064 & 2.7 & -1.8 & 1.5 & 2.9 & 2.4 & 1.9 & 12.9 & 11.1 & Peaty Gley & Granite \\
\hline PG4 & 267 & 14 & 1230 & 2.9 & -1.8 & 1.3 & -4.0 & -3.3 & 5.2 & 28.4 & 10.9 & Peaty Gley & Granite \\
\hline PG5 & 319 & 48 & 2060 & 10.8 & -3.0 & 1.9 & 3.5 & 8.1 & 9.4 & 54.9 & 9.8 & Peaty Gley & Metasediments \\
\hline PP1 & 283 & 352 & 1006 & 10.7 & 0.3 & 2.5 & -54.8 & -46.8 & 38.6 & 153.4 & 5.0 & Peaty Podzol & Granite \\
\hline PP2 & 275 & 230 & 1199 & 7.8 & -0.6 & 2.4 & -51.9 & -48.4 & 28.3 & 142.9 & 7.4 & Peaty Podzol & Granite \\
\hline PP3 & 344 & 544 & 1793 & 12.6 & 0.0 & 2.7 & -33.4 & -23.3 & 20.4 & 96.5 & 7.7 & Peaty Podzol & Metasediments \\
\hline
\end{tabular}

$t_{R}$ lag time
$21^{\text {st }}$ of June $2013-31^{\text {st }}$ of May 2014 data

${ }^{3}$ Topographic Wetness Index 
Table 3: Fraction of time GW level at specific soil depths between 1.6.2013-31.5.2014 [\%] ${ }^{*}$

\begin{tabular}{ccccccccccccccc}
$\begin{array}{c}\text { Fraction of time water } \\
\text { table is in upper }\end{array}$ & P1 & P2 & P3 & P4 & P5 & P6 & PG1 & PG2 & PG4 & PG5 & PP1 & PP2 & PP3 \\
\hline 0cm & 0 & 0 & 0 & 13 & 62 & 78 & 0 & 0 & 26 & 74 & 14 & 0 & 0 \\
$20 \mathrm{~cm}$ & 100 & 94 & 19 & 95 & 100 & 99 & 71 & 8 & 100 & 97 & 18 & 7 & 0 \\
$40 \mathrm{~cm}$ & 100 & 100 & 86 & 100 & 100 & 100 & 88 & 76 & 100 & 99 & 30 & 34 & 80 \\
$60 \mathrm{~cm}$ & 100 & 100 & 100 & 100 & 100 & 100 & 96 & 94 & 100 & 100 & 66 & 75 & 89 \\
&
\end{tabular}

PG3 excluded as not enough data were available 
Table 4: Number of precipitation events used for lag time analysis at the different groundwater loggers

\begin{tabular}{|c|c|c|c|c|c|c|c|c|c|c|c|c|c|c|}
\hline GWL & P1 & P2 & P3 & P4 & P5 & P6 & PG1 & PG2 & PG3 & PG4 & PG5 & PP1 & PP2 & PP3 \\
\hline $\begin{array}{l}\text { No. of P events where GW data } \\
\text { were available }{ }^{* 1}\end{array}$ & 24 & 23 & 16 & 20 & 24 & 24 & 15 & 24 & 12 & 19 & 16 & 24 & 24 & 16 \\
\hline $\begin{array}{l}\text { No. of } P \text { events were correlation } \\
\text { between } Q \text { and } G W \text { data was } \geq 0.5^{* 2} \\
{ }^{*}{ }_{1} 24 \text { precipitation events analysed in }\end{array}$ & $\begin{array}{l}19 \\
\text { total }\end{array}$ & 22 & 11 & 20 & 21 & 23 & 14 & 23 & 11 & 17 & 16 & 14 & 17 & 8 \\
\hline
\end{tabular}


Table 5: Main properties of the selected rainfall-runoff events

\begin{tabular}{lcccc} 
& Spring & Summer & Fall & Winter \\
\hline Number of events & 6 & 6 & 6 & 6 \\
Minimum P (mm) & 8.33 & 3.7 & 4.74 & 5.5 \\
Maximum P (mm) & 74.1 & 27.0 & 74.1 & 27.1 \\
Mean P (mm) & 40.1 & 11.9 & 32.6 & 16.3 \\
Maximum streamflow peak $(\mathrm{mm})$ & 0.55 & 0.12 & 0.32 & 0.34 \\
\% of active wells (upper20cm) & 92 & 72 & 70 & 82
\end{tabular}

